\title{
Has Regulation G Improved the Information Quality of Non-GAAP Earnings Disclosures?
}

\author{
HAN YI* \\ Korea University \\ Seoul, Korea
}

\begin{abstract}
Based on hand-collected non-GAAP earnings disclosures from 2001 to mid 2004, this paper finds that firms with communication motives, proxied by historically low returns-GAAP earnings relation, are more likely to disclose non-GAAP earnings in the post-Reg G period than in the preReg $\mathrm{G}$ period. In contrast, firms with opportunistic motives, proxied by GAAP loss and negative GAAP EPS changes, are less likely to disclose nonGAAP earnings in the post-Reg G period than in the pre-Reg G period. With additional test results, the findings of this paper appear consistent with Congress' and the SEC's intervention in pro-forma reporting practices resulting in improvements in the quality of information provided in nonGAAP earnings disclosures.
\end{abstract}

Keywords: Non-GAAP (Pro-forma) Earnings; Regulation G; Sarbanes-Oxley Act of 2002; Strategic Disclosures; Earnings Informativeness

\footnotetext{
Assistant Professor of Accounting. Korea University. E-mail: hanyi@korea.ac.kr Mailing Address: LG-POSCO 608, Korea University Business School, Anamdong, Seongbuk-gu. Seoul 136-701, Korea. Voice: +82-2-3290-2629. This paper is based on my dissertation completed at Michigan State University. I would like to thank my committee members: Thomas Linsmeier (Chair), Kathy Petroni, K. Ramesh and Jennifer Marietta-Westberg. I also thank the following for their helpful comments and suggestions: Eli Amir, Bruce Bettinghaus, Christine Botosan, Amy Choy, Angela Davis, Jeffrey Doyle, Marilyn Johnson, Bob Lipe, Christian Mastilak, Pervin Schroff, Chandra Subramaniam, Wayne Thomas, Ivy Zhang, and workshop participants at the 2005 American Accounting Association Annual Meeting, the University of Alberta, Iowa State University, London Business School, the University of Minnesota, Michigan State University, the University of Oklahoma, the University of Texas-Arlington, and the University of Utah. I acknowledge the able research assistance of Michelle Liu, Joe Viraldo, Eunsun Yang and Huifang Zhu. I also appreciate the financial support from the Michael F. Price College of Business at the University of Oklahoma and Korea University. All remaining errors are mine.
} 


\section{INTRODUCTION}

In response to the highly publicized alleged misuse of pro-forma earnings disclosures, the U.S. Congress ordered the Securities and Exchange Commission (SEC) to issue new rules governing the presentation of non-GAAP financial metrics. The goal was to improve the quality and transparency of financial accounting information (Section 401(b) of the Sarbanes-Oxley Act of 2002). The SEC released Regulation G (SEC 2003a, hereinafter referred to as "Reg G") in January of 2003. Reg G requires firms that disclose non-GAAP earnings in preliminary earnings announcements to clearly reconcile non-GAAP earnings to GAAP earnings with equal emphasis on both figures. Recent studies by Heflin and Hsu (2005) and Marques (2006) and a survey by the National Investor Relations Institute (2003) have documented a significant decline in non-GAAP earnings disclosures after the SEC intervention. This paper examines whether the decreased frequency of non-GAAP earnings disclosures post-Reg $G$ reflects intended or unintended consequences of Reg G (and the Sarbanes-Oxley Act of 2002).

Business journalists, citing conflicting anecdotes, continue to make divergent claims as to whether or not Reg G has effectively eliminated disclosures of misleading non-GAAP earnings in preliminary earnings announcements. Some view Reg G to be a lax enforcement mechanism, arguing that firms can still characterize routine expenses as special charges to justify reversing these items in arriving at non-GAAP earnings, thus misleading investors' perceptions about firm performance (e.g., Stuart 2004, Taub 2003). Alternatively, others believe that Reg G helps investors unravel the firm's strategic motives underlying the disclosure of non-GAAP earnings, discouraging firms with opportunistic disclosure motives from misleading investors (e.g., Henry 2003; Thompson 2003).

Extant academic evidence examining the disclosure of nonGAAP earnings (or Street earnings or pro-forma earnings) prior to Reg G leaves two unresolved issues: (1) whether these earnings numbers are an attempt to help investors (e.g., Bhattacharya et al. 2003; Bradshaw and Sloan 2002; Brown and Sivakumar 2003; Doyle, Lundholm, and Soliman 2003; Vincent 1999) or an attempt to alter investors' perceptions about a firm's ability to meet or beat 
various earnings benchmarks (e.g., Bowen, Davis, Matsumoto 2005; Frederickson and Miller 2004; Hirshleifer and Teoh 2003; Lougee and Marquardt 2004; Schrand and Walther 2000), and (2) who the promulgators of these earnings figures are - management or sellside analysts or forecast data providers (e.g., Abarbanell and Lehavy 2007; Christensen 2007; Bhattacharya, Black, Christensen, and Mergenthaler 2007).

Studies examining non-GAAP earnings disclosures post Reg G report a decline of non-GAAP earnings disclosures (e.g., Baik, Billings, and Morton 2006, Heflin and Hsu 2011; Marques 2006; Kolev, Marquardt, and McVay 2008; Zhang and Zheng 2011). However, disclosure determinant analyses in these studies are designed to report the disclosure frequency change after a series of SEC interventions, and thus do not explicitly recognize two aforementioned strategic disclosure motives. In addition, some of these studies use analysts' EPS definitions provided by forecast data providers such as I/B/E/ $\mathrm{S}$, limiting inferences about the impact of Reg G on managers' nonGAAP earnings disclosures (e.g., Heflin and Hsu 2005, Kolev et al. 2007). These studies also provide mixed evidence on whether Reg G has achieved the goal that Congress and the SEC has intended. For example, while Marques (2006) documents that market participants negatively value additional non-GAAP adjustments made by managers in the post Reg G period (i.e., an unintended consequence), Heflin and Hsu (2005) document that non-GAAP earnings are less likely to slightly meet or beat analysts' earnings forecast in the post-Reg G period (i.e., an intended consequence).

Given that Reg G addresses the presentation format of a specific voluntary disclosure item in earnings announcements, I recognize two conflicting, but not mutually exclusive, strategic disclosure motives reported in prior literature in this study. Based on prior research, I assume communication motives for low GAAP earnings relevance firms, as proxied by a low GAAP earnings-security return relationship (Bradshaw and Sloan 2002; Lougee and Marquardt 2004), because managers of these firms likely wish to exclude transitory amounts from their GAAP earnings to better communicate with users of the earnings. I assume opportunistic motives for firms disclosing non-GAAP earnings when these firms' GAAP earnings fall short of various earnings benchmarks. If Reg G resulted in fewer firms disclosing non-GAAP earnings to mislead investors, then Reg G has achieved its objective. Alternatively, if Reg G resulted in fewer 
firms reporting non-GAAP earnings to better inform investors, then Reg $G$ has had adverse unintended consequences. Taking the reported decrease in non-GAAP earnings disclosures as given, I focus on whether the reported decreased non-GAAP earnings disclosure frequency implies intended or unintended consequences of Reg G. In addition, I focus on adjusted EPS numbers by managers ${ }^{1)}$ instead of actual EPS provided by forecast data providers because I believe the first order impact of Reg G is on managers' behaviors rather than sell-side analysts' behaviors. ${ }^{2}$

I manually collect 10,896 actual press releases of 792 randomly selected firms from the intersection of CRSP and COMPUSTAT and spanning 2001 to mid 2004. Based on this dataset, I investigate the post-Reg G changes in: (1) the motives of managers for disclosing non-GAAP earnings, (2) the perception of investors regarding the relevance of non-GAAP earnings (i.e., the changes in the incremental information content of non-GAAP earnings over GAAP earnings), and (3) the extent to which so called "pro-forma earnings hype" misleads investors (i.e., the changes in the negative associations between income-increasing non-GAAP adjustment and future performance indicators), and report the following results.

First, I find that non-GAAP earnings disclosures are more pronounced for sample firms with lower historical GAAP earningssecurity return relationships (i.e., high communication motives) in the post-Reg $G$ period than in the pre-Reg $G$ period. In contrast, I find that non-GAAP earnings disclosures are less pronounced for sample firms with losses or negative GAAP earnings changes (i.e., possible opportunistic motives) in the post-Reg G period than in the pre-Reg G period. These results imply that decreased disclosure of non-GAAP earnings post Reg $\mathrm{G}$ is more pronounced for firms with opportunistic motives than for firms with communication motives.

1) Following Regulation G, I use the term "non-GAAP earnings" to capture the concept of management-defined earnings, which prior literature often refers to as pro-forma earnings. Throughout this paper, I use pro-forma earnings and nonGAAP earnings interchangeably.

2) If analysts' exclusions or inclusions of non-recurring items (e.g., Gu and Chen 2004) are affected by how managers define their adjusted EPS in earnings announcements, the Reg G's impact on managers' choices about non-GAAP earnings disclosures may also affect analysts' EPS definitions (i.e., the second order effect). However, it is not clear whether Reg G would directly change analysts' or forecast data providers' incentives relating to their EPS definitions. I leave it for another research. 
Second, I find that non-GAAP earnings were incrementally informative over GAAP earnings in the post-Reg G period (2003:042004:08) while there was no incremental information content of non-GAAP earnings over GAAP earnings in the pre-Reg G period (2001:01-2003:03). Further analyses show that no evidence on the informativeness of non-GAAP earnings in the pre Reg G period sample firm-quarters is attributable to firms that discontinued disclosing non-GAAP earnings post Reg G. This implies that there were firms that disclosed less-relevant non-GAAP earnings in the preReg $\mathrm{G}$ period and Reg $\mathrm{G}$ has discouraged these firms from disclosing non-GAAP earnings post Reg G.

Third, I regress (1) one-year value-weighted size/book-to-market/ momentum adjusted buy-and-hold returns (Daniel et al. 1997) and (2) the four-quarters ahead operating income on the income-increasing non-GAAP adjustments made by managers, allowing the relations to vary pre- and post-Reg G. Prior studies docuement negative associations between income-increasing non-GAAP earnings adjustment and future performance indicators, indicating that managers may mislead investors with earnings-hype (e.g., Dolye, Lundholm, and Soliman 2003; Frankel, McVay, and Soliman 2011). Consistent with these studies, I find negative associations between the nonGAAP adjustment and future returns/future operating income in the pre-Reg G period sample firm-quarters. However, I find that these negative associations are not statistically significant in the post Reg G period sample firm-quarters. Further analyses show that negative associations reported in the pre Reg G period were mainly due to firms that had stopped disclosing non-GAAP earnings in the post Reg G period. This implies that there were firms that made misleading or non-transitory income-increasing non-GAAP adjustments in the pre-Reg $G$ period and Reg $G$ has discouraged these firms from disclosing non-GAAP earnings post Reg G.

These results suggest that Reg G's enhanced disclosure requirements discouraged managers from opportunistically disclosing non-GAAP earnings in the post Reg G period, and investors consequently perceive surviving non-GAAP earnings as more transparent in the post-Reg G period than in the pre-Reg $\mathrm{G}$ period. Overall, the findings of this paper appear consistent with Congress' and the SEC's intervention in pro-forma reporting practices resulting in improvements in the quality of information provided in non-GAAP earnings disclosures by discouraging 
opportunistic managers' presentation of non-GAAP earnings disclosures.

This paper makes two contributions to the literature. First, the study provides evidence that addresses the calls of Dechow and Schrand (2004, p.116) and Stuart (2004) for research on the effects of Reg G (and the Sarbanes-Oxley Act of 2002) on firms' (mis)use of pro-forma earnings disclosures. Building upon the documented decrease in non-GAAP earnings disclosures post Reg G in Heflin and Hsu (2005) and Marques (2006), I further investigate the issue of whether the Sarbanes-Oxley Act has discouraged misleading nonGAAP earnings (intended consequences) or informative non-GAAP earnings (unintended consequences) by explicitly recognizing two strategic disclosure motives from prior literature (e.g., Lougee and Marquardt 2004). Thus, this study adds to a growing body of literature that examines the consequences of the Sarbanes-Oxley Act (e.g., Cohen, Dey, and Lys 2008; Doyle, Ge, and McVay 2006, Zhang 2007) by studying a disclosure dimension of the Act.

Second, this paper adds to the debate regarding the transparency of pro-forma earnings (e.g., Bradshaw 2003) by providing evidence that some pro-forma earnings were used as a means to obfuscate investors' perception about firm performance in the pre-Reg G period. The dual findings of this study that opportunistic managers are discouraged from providing non-GAAP earnings in the post-Reg G period and that the market values both GAAP and non-GAAP earnings' transparency in the post-Reg G period imply that some firms disclosed non-GAAP earnings opportunistically in the less regulated environment. In addition, the results imply that managers may factor in investors' expected judgment improvement with enhanced disclosure formats (e.g., Elliott 2006, Hobson and Kachelmeier 2005) in their non-GAAP earnings disclosure decisions.

The remainder of the paper continues as follows. The following section provides the background, reviews relevant literature, and develops the research hypotheses. Section 2 describes the sample selection and provides descriptive statistics. Section 3 presents the research design as well as the empirical findings of the analyses. Section 4 summarizes and concludes. 


\section{BACKGROUND, LITERATURE REVIEW AND HYPOTHESES DEVELOPMENT}

\section{Background and literature review}

Although the SEC adopted the term "non-GAAP financial measures" in Reg G, what triggered the legislative action was the proliferation in the late 1990's of so-called "pro-forma earnings" disclosures. "Pro-forma earnings" has become the term used to describe a firm's voluntary disclosure of earnings that deviate from GAAP earnings (Bradshaw 2003).

Advocates of pro-forma earnings argue that managers, especially in the high growth technology sectors, may wish to disclose nonGAAP earnings to adjust irrelevant historical costs and to better communicate with the capital markets (Taub 2001; Thurm and Weil 2001). One stream of research suggests that non-GAAP earnings function as a supplement to less relevant GAAP earnings. Consistent with this view, Lougee and Marquardt (2004) find that proforma earnings are more pronounced from firms with less relevant GAAP earnings characteristics (e.g., Collins, Maydew and Weiss 1997; Francis and Schipper 1999; Lev and Zarowin 1999). A number of studies also document that, within firms with less relevant GAAP earnings, non-GAAP earnings are less conservative than GAAP earnings and have higher explanatory power for contemporaneous returns, price, and future operating performance than do GAAP earnings (Bradshaw and Sloan 2002; Brown and Sivakumar 2003; Frankel and Roychowdhury 2004; Doyle, Lundholm, and Soliman 2003).

However, critics often indicate that managers (1) provide insufficient information to reconcile GAAP and non-GAAP earnings, (2) focus greater attention on non-GAAP earnings, and (3) select adjustment items inconsistently to upward bias non-GAAP earnings by desired amounts, possibly misleading investors about firm performance (Weil 2001). Consistent with this view, a line of research suggests that managers may selectively report items in earnings announcements as a strategic tool either to alter investors' perception about the firm's performance or to change perceptions about its ability to meet or beat various earnings benchmarks (e.g., Bhattacharya et al. 2003; Bowen, Davis, and Matsumoto 2005; Doyle, 
Jennings, and Soliman 2011; Elliott 2006; Frederickson and Miller 2004; McVay 2006; Schrand and Walther 2000). A long-window pricing study by Doyle, Lundholm, and Soliman (2003) provides confirmatory evidence for this argument by reporting a strong negative association between non-GAAP adjustments and future performance.

Other evidence suggests that these two disclosure motives (communication vs. opportunism) are not mutually exclusive. For example, the CFO Magazine and KPMG joint survey of 196 financial executives at an FEI conference reveals the conflicting motives concerning the presentation of pro-forma earnings, viz. (1) to convey true performance (45\%), (2) to meet the demands of analysts $(27 \%)$, and (3) to help "put the best spin on the results" (25\%) (Goff 2001).

Despite this mixed evidence, however, a spate of financial frauds at the end of the tech bubble has led the financial press to focus on the potentially problematic use of pro-forma earnings, and triggered legislative action. ${ }^{3)}$ The Sarbanes-Oxley Act of 2002 was signed into law by President Bush on July 30, 2002. The SEC's implementation of Section 401(b) of the Act ("Conditions for Using non-GAAP Financial Measures," hereafter "the Rules", January 22, 2003, see SEC 2003a) followed a two-step approach to deal with the issues identified by critics of pro-forma earnings (see SEC 2003b, NIRI 2001, 2002). ${ }^{41}$

3) Prior to Reg G, both private-sector organizations and the SEC alerted firms to the risks relating to non-GAAP earnings information. Two influential privatesector organizations, Financial Executives International and the National Investor Relations Institute, proposed industry guidelines for reporting pro-forma earnings (NIRI 2001, 2002). The SEC supported the guidelines suggested by FEI and NIRI, and it reminded firms of the importance of antifraud provisions and materiality in the pro-forma earnings context (the SEC's cautionary advice, see SEC 2001).

4) In the first step, the Rules introduce new requirements for non-GAAP earnings disclosures provided in public communications other than SEC filings (e.g., earnings releases and conference calls). Specifically, Reg G requires firms in earnings releases and other public non-SEC filings to provide reconciliations of non-GAAP earnings to GAAP earnings with equal emphasis on both numbers. In addition, within four business days of releasing an earnings release containing non-GAAP earnings, firms should disclose in item 12 of Form 8-K both GAAP and non-GAAP amounts and the reason why management believes the nonGAAP measure is useful to investors. The second step is geared towards dealing with inconsistency in adjustment items. If firms additionally disclose non-GAAP earnings in SEC filings, the Rules give a set of specific guidelines about what should not be excluded or included in the calculation of non-GAAP earnings. Because this requirement is highly likely to discourage firms from presenting non-GAAP earnings, the SEC restricts this requirement only to non-GAAP 
Reg G does not impose restriction on voluntary disclosure of nonGAAP earnings per se. Reg G instead regulates the presentation of the voluntary disclosure by requiring firms in earnings releases and other public non-SEC filings to provide reconciliations of non-GAAP earnings to GAAP earnings with equal emphasis on both numbers. Because of this aspect of Reg G, the SEC expected that Reg G would have little impact on disclosure per se (e.g., see SEC 2003a). For example, an SEC spokesman was reported to say:

"We don't expect less disclosure, we expect more meaningful disclosure. There's nothing in the rule that precludes people from providing information that they want to provide to investors, just as long as it's reconciled" (Babington 2003)

However, recent studies document that non-GAAP earnings disclosures have significantly decreased after Reg G (Heflin and Hsu 2005, Marques 2006, NIRI 2003). Given mixed evidence on the transparency of non-GAAP earnings disclosures in the pre-Reg G period, the decreased disclosure frequency of non-GAAP earnings after Reg G could be attributed either to the success or failure of the U.S. Congress' and the SEC's efforts depending upon whether Reg G results in fewer firms disclosing non-GAAP earnings that mislead investors (intended consequence) or fewer firms reporting non-GAAP earnings that better inform investors (unintended consequence). Accordingly, both academics and business journalists call for research on the effect of Reg G on firms' (mis)use of pro-forma earnings disclosures (Dechow and Schrand 2004, p. 116; Stuart 2004).

Papers examining Reg G's consequences (e.g., Baik, Billings, and Morton. 2006; Heflin and Hsu 2011; Marques 2006, Zhang and Zheng 2011) report decreased non-GAAP earnings disclosures in the post Reg G period. However, disclosure determinant analyses in these studies did not recognize the conflicting disclosure motives reported in Lougee and Marquardt (2004). Also, many studies (e.g., Heflin and Hsu 2011; Kolev, Marquardt, and McVay 2006) use actual EPS provided by forecast data providers, limiting inferences about the Reg G's impact on managerial motives changes. In addition, some studies imply different consequences of Reg G. For example, while Marques (2006) documents that market participants 
negatively value non-GAAP adjustments made by managers (i.e., an unintended consequence), ${ }^{5}$ Heflin and Hsu (2011) document that non-GAAP earnings are less likely to slightly meet or beat analysts' earnings forecast in the post-Reg G period (i.e., an intended consequence). Kolev, Marquardt, and McVay (2008) reported that some firms responded to Reg G by classification shifting. Zhang and Zheng (2011) show that reconciliation helps investors figure out the hidden motives behind the disclosure of non-GAAP earnings.

My study differs from these studies in two regards. First, given that Reg $\mathrm{G}$ addresses the presentation format of a specific voluntary disclosure item in earnings announcements, I recognize two conflicting, but not mutually exclusive, strategic disclosure motives reported in prior literature (i.e., communication vs. opportunism) in this study. I also focus on hand-collected adjusted EPS numbers by managers instead of actual EPS provided by forecast data providers to avoid confounding inferences from analysts' EPS definitions provided by forecast data providers.

\section{Hypotheses Development}

As noted above, there are at least two plausible scenarios consistent with the reported decreased disclosure of non-GAAP earnings in the post Reg G period. One possibility is that, as business journalists contend, a mere reporting requirement such as Reg G would have not discouraged firms with opportunistic motives from reversing routine expenses as special charges in deriving non-GAAP earnings. This could be the case insofar as income-increasing non-GAAP adjustment items are technically permitted under the Rules (e.g., Countryman 2003; Stuart 2004; Taub 2003). Chuck Hill, former director of research at Thomson Financial First Call, was reported to say:

"While few are blatantly breaking the law by omitting GAAP equivalents or reconciliation tables, some companies are taking advantage of the relatively lax enforcement of regulations on press releases to spin their numbers in ways that would be illegal in

5) If the market is efficient and the reconciliation of Reg G helps investors better evaluate the transparency of non-GAAP adjustments, negative valuation of nonGAAP adjustments made by managers suggests non-GAAP adjustments in the post Reg G period are likely to be made by opportunistic managers. 
official filings" (see Stuart 2004)

At the same time, Reg $G$ might make managers with communication purposes overly sensitized to investors' skepticism about non-GAAP earnings in the post-Reg $\mathrm{G}$ period by regulating how non-GAAP presentation should look in the earnings announcement. For example, Robert Willens, an accounting analyst at Lehman Brothers, says:

"A lot of people are gun shy about unwittingly providing information that could ... be seen as misleading." (see Babington 2003).

This could perhaps cause firms with communication motives to reconsider providing non-GAAP earnings information. These scenarios imply the possibility of Reg G's adverse unintended consequence.

The other possibility is that Reg G has in two ways effectively mitigated the incentive to disclose non-GAAP earnings to mislead investors. First, the Sarbanes-Oxley Act enacted higher penalties for those managers who are opportunistic in their financial disclosures. Second, Reg G's enhanced reporting requirements can help investors better assess the value relevance of an information cue by (1) reducing cognitive processing costs and (2) helping investors avoid functionally fixating on the saliently presented information cue (e.g., Dietrich et al. 2001; Maines and McDaniel 2000; Elliott 2006; Hirshleifer and Teoh 2003). If managers rationally factored in the effect of enhanced disclosure on the investors' ability to evaluate firm performance, managers with better communication motives would continue to present non-GAAP earnings disclosure while managers with opportunistic motives would not. This scenario is well summarized in the comment of Martin Dunn, who was the Deputy Director of the SEC's Corporation Finance Division and drafted Reg G (see Henry 2003):

"Companies supplying numbers that aren't based on GAAP must explain fully and prominently how and why they differ, even in press releases and Webcast conferences. The new explanations, along with required side-by-side comparisons of GAAP and pro forma earnings, will flash like yellow caution signals to skeptical 
investors, the SEC believes. Companies are going to be thinking longer and harder before putting out non-GAAP numbers. They know they are going to have to justify and reconcile."

To distinguish these two alternative consequences, I provide five testable hypotheses.

Comparison of disclosure motives across time.

If Reg $\mathrm{G}$ had the consequences intended by Congress and the SEC, then the association between non-GAAP earnings disclosures and communication motives increased in the post-Reg $G$ period and/or the association between non-GAAP earnings disclosures and opportunistic disclosure motives declined in the post-Reg G period. In contrast, if Reg $\mathrm{G}$ has had consequences unintended by Congress and the SEC, then the association between non-GAAP earnings disclosures and communication motives declined in the post-Reg G period and/or the association between non-GAAP earnings disclosures and opportunistic motives increased in the post-Reg G period. Because these two disclosure motives are not mutually exclusive, I provide two separate hypotheses in the alternative form under the scenario of Reg G being successful.

H1: (Communication motives and Reg G) Reg G being successful, the incremental propensity of firms to disclose nonGAAP earnings to communicate the economic prospects of firms rather than to opportunistically mislead investors has increased over the pre- and post-Reg G periods.

H2: (Opportunistic motives and Reg G) Reg G being successful, the incremental propensity of firms to issue non-GAAP earnings to opportunistically mislead investors' perceptions about firm performance rather than to communicate economic prospects has decreased over the pre- and post-Reg G periods.

Comparison of Market's Perception of non-GAAP Earnings across Time.

The next hypothesis relates to the incremental information content of non-GAAP earnings surprises in addition to GAAP earnings surprises across the pre- and post-Reg G periods. My goal with this hypothesis is to examine whether inferences from $\mathrm{H} 1$ and $\mathrm{H} 2$ are 
consistent with the market's perception of the transparency of nonGAAP earnings in the post-Reg G period. Assuming that with the help of increased disclosure requirements investors can determine the transparency of non-GAAP earnings more efficiently in the postReg G period than in the pre-Reg G period, I posit two plausible scenarios. On one hand, if Reg $G$ is effective such that firms with communication (opportunistic) motives are more (less) likely to disclose non-GAAP earnings in the post-Reg G period than in the pre-Reg G period, it is likely that the incremental information content of nonGAAP earnings was greater in the post-Reg G period than in the preReg $G$ period. On the other hand, if Reg $G$ is not effective, it is likely that the incremental information content of non-GAAP earnings was either unchanged or smaller in the post-Reg G period than in the pre-Reg G period. This discussion leads to the following hypothesis in the alternative form.

H3: (Incremental information content of non-GAAP earnings and Reg G) Reg G being successful, the incremental information content of non-GAAP earnings over GAAP earnings has not changed over the pre- and post-Reg $G$ regimes.

Comparison of the Quality of Income-increasing Non-GAAP Adjustments over Time.

Prior studies report negative associations between income-increasing non-GAAP adjustments and future performance indicators, suggesting that managers may provide misleading or non-transitory income-increasing non-GAAP adjustments (Doyle, Lundholm and Soliman. 2003, Frankel, McVay, and Soliman 2011). ${ }^{6)}$ If Reg G is effective, it is likely that the expected negative associations between income-increasing non-GAAP adjustment and future performance indicators became weaker in the post-Reg $\mathrm{G}$ period. On the other hand, if Reg G is not effective, it is likely that these negative associations continued to exist in the post-Reg $\mathrm{G}$ period. This discussion leads to the following hypotheses in the alternative form.

H4: (The association between income-increasing non-GAAP

6) On the other hand, there are no clear theoretical predictions about incomedecreasing non-GAAP earnings and future performance metrics. Thus, I focus only on income-increasing non-GAAP adjustment in testing $\mathrm{H} 4$ and $\mathrm{H} 5$. 
adjustment and future abnormal stock returns) Reg G being successful, the expected negative association between incomeincreasing non-GAAP adjustment and future abnormal stock returns in the pre-Reg $G$ period would be no longer negative in the post- Reg G regimes.

H5: (The association between income-increasing non-GAAP adjustment and future operating income) Reg G being successful, the expected negative association between income-increasing nonGAAP adjustment and future operating income in the pre-Reg $G$ period would be no longer negative in the post-Reg G regimes.

\section{SAMPLE SELECTION AND DESCRIPTIVE STATISTICS}

\section{Sample Selection}

I first determine sample firms of interest and then manually collect press releases for those firms over the sample period, constructing sample firm-quarters similar to a panel dataset. ${ }^{7)}$ Table

7) My sample selection strategy has several advantages that other studies do not have. First, studies using the difference between I/B/E/S actual earnings and GAAP earnings as an empirical proxy for the disclosure of non-GAAP earnings (e.g., Heflin and Hsu 2011; Kolev, Marqurdt, and Mcvay 2008) have three issues in drawing inferences: (1) conceptually, earnings adjusted by managers are not identical to earnings adjusted by analysts because of different incentives relating to managers and analysts, (2) the disclosure, magnitude, and adjustment of nonGAAP earnings are often significantly different from those of earnings adjusted by either analysts or I/B/E/S (see Bhattacharya et al. 2008; Marques 2006), and (3) the intersection of I/B/E/S and COMPUSTAT does not translate well into the demographic profile of non-GAAP earnings disclosures (e.g., firm size and industries), limiting inferences about the impact of Reg G on the population of firms (see Bhattacharya et al. 2008). Second, another approach for the sample selection is to use key-word search through press releases databases (e.g., Bowen, Davis, and Matsumoto 2005; Zhang and Zheng 2011). This approach is presumably better than the former approach in terms of the measurement error of non-GAAP earnings disclosures. Because language seems to play an important role in pro-forma earnings disclosures (Bradshaw 2003; Wallace 2002), however, it is likely that the sample firms in the post-Reg G period from the keyword search approach may suffer from a self-selection issue. For example, if firms tend to avoid the nomenclature of "pro-forma" earnings in the post-Reg G period to avoid scrutiny from investors, a study that extracts sample firms based on the "pro-forma" key-word may generate under-represented sample firms, leading to an erroneous conclusion. Third, although the sample selection approach in Marques (2006) resembles my sample selection, her sample firms are biased 


\section{Table 1 Sample selection}

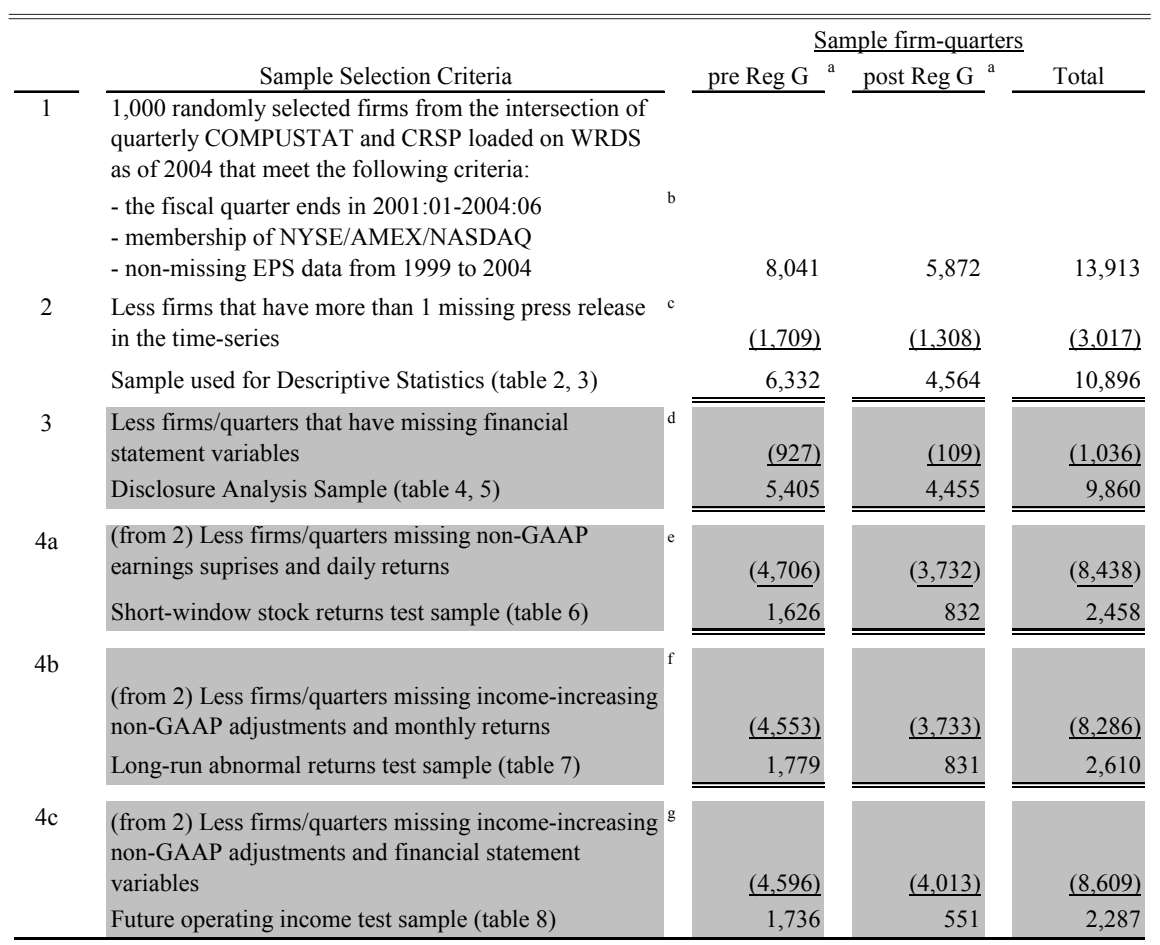

Note: a. Regulation G applies to all public disclosures, including earnings releases and filings with the SEC, made after March 28, 2003. Because the focus of this paper is earnings releases, I divide firm-quarter observations into the pre- and post- Reg G observations based on each firm-quarter's preliminary earnings announcement date. Thus, preliminary earnings announcement date after March 28, 2003 is classified as the post-Reg G observations.

b. The sample starts from quarters after 2001 in order to make sure that inferences are not affected by Regulation Fair Disclosure. The fiscal quarter of sample firms ends at 2004:06 due to financial statement variables availability from COMPUSTAT.

c. I eliminate observations that have more than 1 missing observation in 2001:01-2004:06 time series to construct a pseudo panel dataset.

d. The test in table 5 requires a dummy variable indicating whether the firm has disclosed non-GAAP earnings in the prior quarter (PRIORNG). Accordingly, I lose the first observation from each firm's time-series.

e. The test in table 6 requires seasonally differenced GAAP and non-GAAP earnings surprises as well as daily return data.

f. The test in table 7 requires income increasing non-GAAP earnings adjustments as well as monthly stock return data.

g. The test in table 8 requires income increasing non-GAAP earnings adjustments as well as one year ahead operating income per share. 
1 summarizes my sample selection approach. I randomly draw 1,000 firms from the intersection of CRSP and COMPUSTAT as of 2004. Sample firms in the initial random sampling meet the following criteria: (1) the fiscal quarter ends (i.e., FQENDDT in COMPUSTAT) in 2001:01-2004:06 range, (2) membership on NYSE/AMEX/ NASDAQ, and (3) availability of EPS data from 1999 to 2004. The first requirement makes sure that inferences are not confounded by including the pre-Regulation Fair Disclosure (Reg FD) periods (e.g., my sample encompasses only post Reg FD periods). The second requirement is added to facilitate the acquisition of press releases of sample firms from public databases. The final requirement provides sufficient time-series of observations to permit estimation of an empirical proxy for communication motives (t-statistics from firmspecific regressions of returns on GAAP EPS). ${ }^{8)}$ This process yields 13,913 initial firm-quarters.

I search preliminary earnings announcement press releases of those firms, collecting 12,238 press releases from 944 firms. ${ }^{91} \mathrm{I}$ include sample firms that have less than or equal to one missing observation in their time-series to make my sample firm-quarters similar to a panel dataset (792 firms' 10,896 firm-quarters). Out of 10,896 press releases, I identify 3,228 non-GAAP earnings disclosures. I exclude 927 firm-quarter observations when testing $\mathrm{H} 1$ and $\mathrm{H} 2$ due to unavailability of financial statement variables. Finally, out of 3,228 non-GAAP earnings disclosures, I use 2,458, 2,610, and 2,287 observations to $\mathrm{H} 3, \mathrm{H} 4$, and $\mathrm{H} 5$ respectively depending upon different specification requirements.

\section{Descriptive Statistics}

Panel A of table 2 provides descriptive statistics about the fre-

to bigger firms (e.g., S\&P 500 firms). If bigger firms had been subject to severe public scrutiny even in the pre-Reg G period, studies with bigger firms might conclude that there was no evidence of the misuse of pro-forma earnings and, therefore, no justification of the SEC's intervention.

8) Some may view my sample selection procedure will bring a survivorship bias. However, note that including non-surviving firms will "strengthen" my findings because non-surviving firms are likely to suffer from bad earnings performance and therefore are more likely to use non-GAAP earnings to alter investors' perceptions opportunistically in the pre Reg G period.

9) The proportion of firms issuing preliminary earnings releases is qualitatively similar to that in Amir and Livnat (2005). 


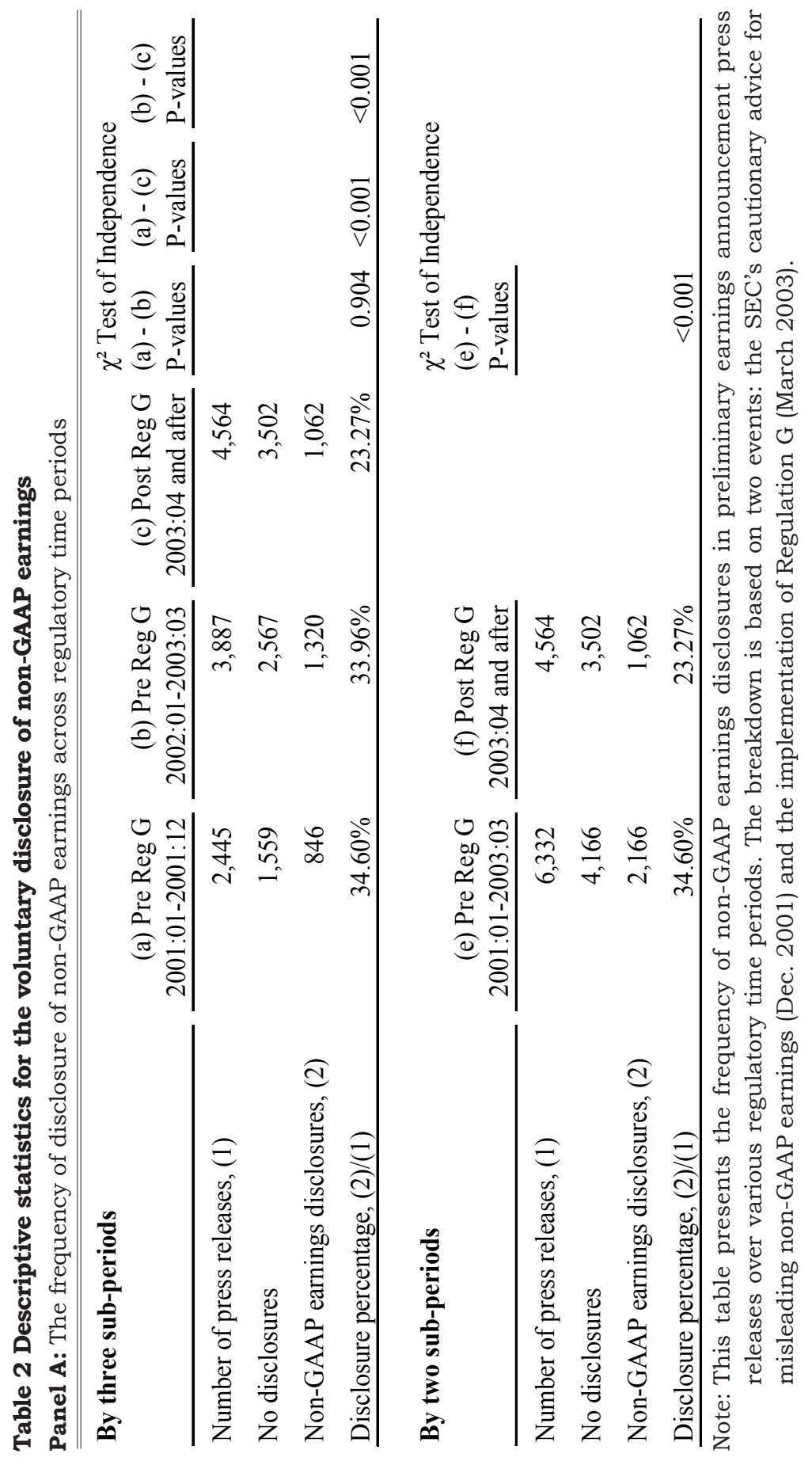


quency of non-GAAP earnings over time. I first divided the sample firm-quarters into three regulatory regimes based on their earnings announcement dates: (1) 2001:01-2001:12 (pre Reg G (1) period), (2) 2002:01-2003:03 (pre Reg G (2) period), and (3) after 2003:03 (post Reg G period). I divide the pre-Reg G period to check whether other preceding events in the pre-Reg G (2) period (e.g., the SEC's cautionary advice as of December 2001, a series of corporate scandals, or the passage of Sarbanes-Oxley Act of 2002 etc.) affected the disclosure frequency of non-GAAP earnings prior to issuance of Reg G. For the three time periods, 34.6\%, 33.96\%, and $23.27 \%$ of firmquarters disclosed non-GAAP earnings in their preliminary earnings announcement press releases, respectively. This result is consistent with Heflin and Hsu (2005) and Marques (2006) in terms of the overall declining reporting frequency.

Panel B of table 2 provides industry breakdowns (Barth et al. 1998) for the disclosure of non-GAAP earnings. Reflecting my random selection procedure, the industry composition of sample firmquarters (row (2)) closely parallels that of COMPUSTAT/CRSP firms as of 2004 (row (1)). The industries where non-GAAP earnings are more pronounced than their sample composition (row (6)) include insurance and real estate, chemicals, computer, transportation, and service and others.

Panel A of table 3 compares non-GAAP EPS, I/B/E/S actual EPS, GAAP EPS excluding extraordinary items and discontinued operations, and S\&P Core EPS (see Blitzer and Friedman (2002) for the

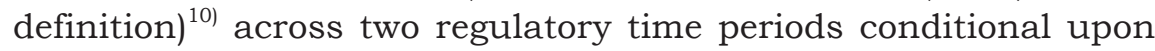
non-GAAP earnings disclosures. Three points are noteworthy. First, all EPSs but non-GAAP EPS have increased over time ((a) through (d), p-values less than 0.05 except the mean difference of non-GAAP EPS), indicating that earnings performance in the post-Reg G period is better than in the pre-Reg G period. Second, non-GAAP EPS always is greater than other EPS metrics ((e) through $(g)$, p-values less than 0.01), but the magnitude of difference between non-GAAP

10) The Standard and Poor's core EPS excludes any gains related to pension activities, net revenues from the sale of assets, impairment of goodwill charges, prior-year charge and provision reversals, and settlements related to litigation or insurance claims. Expenses related to employee stock option grants, pensions, restructuring of present operations or any merger and acquisition costs, R\&D purchases, write-downs of depreciable or amortizable operating assets, and unrealized gains/losses from hedging activities are all included in the core EPS. 


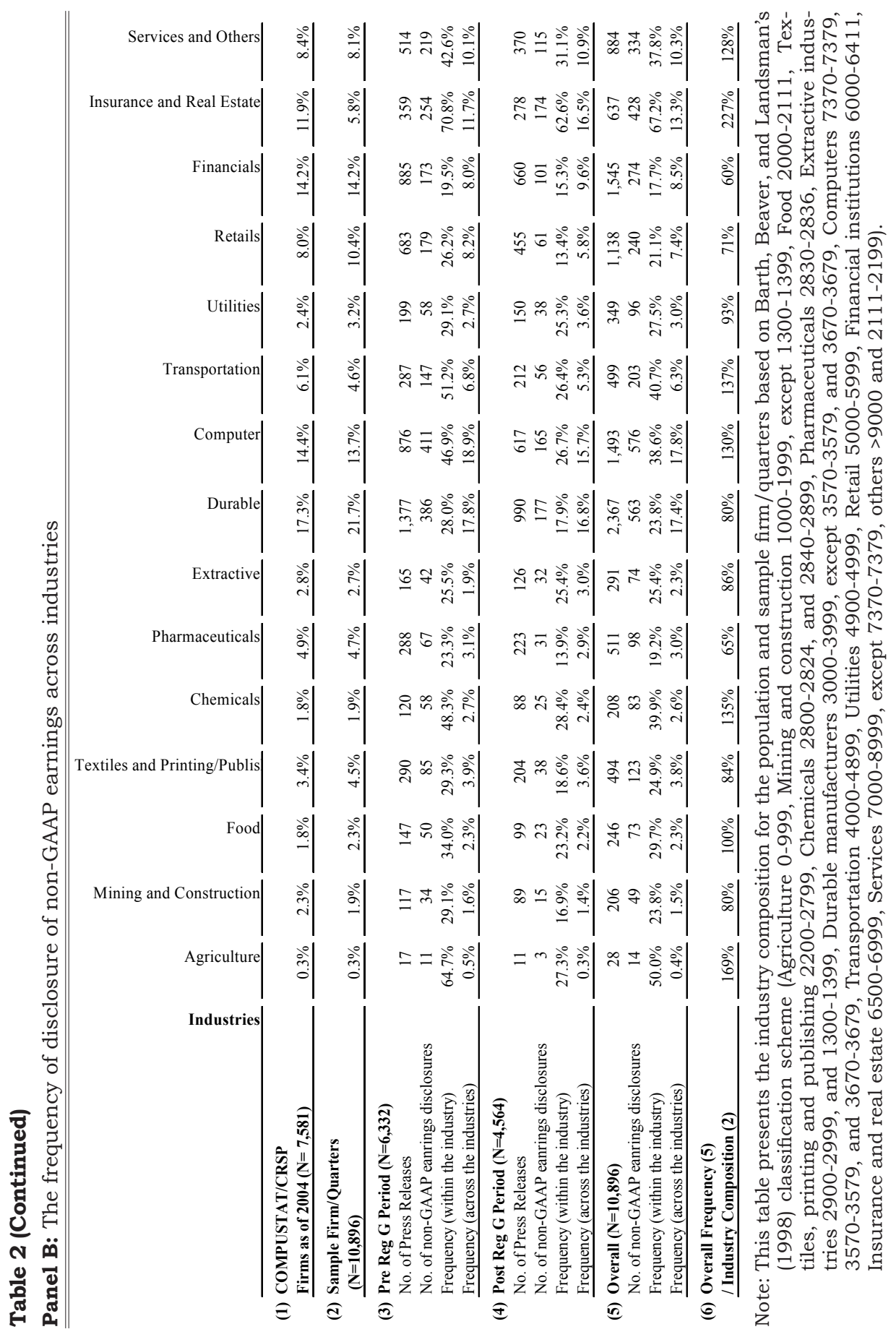




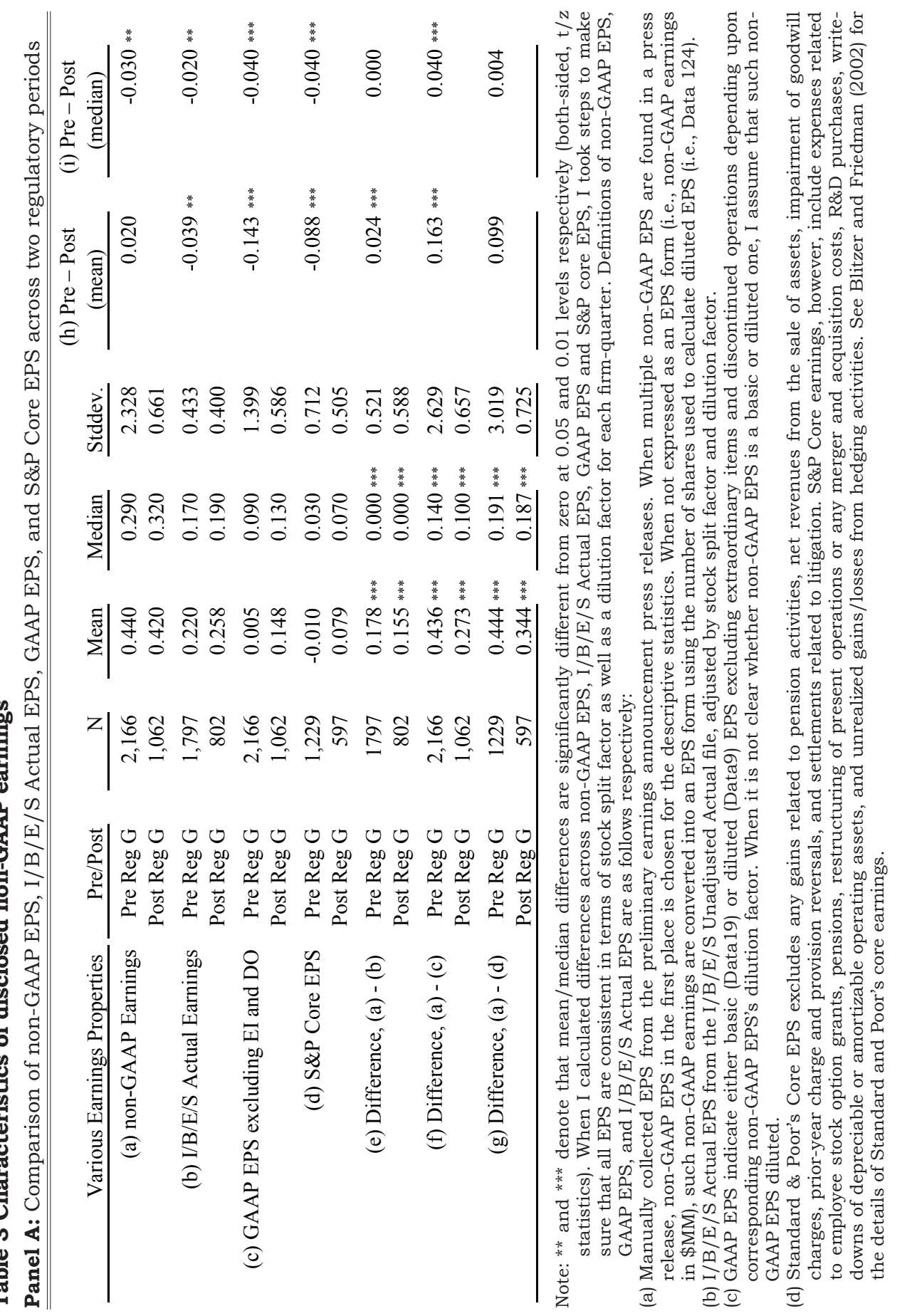




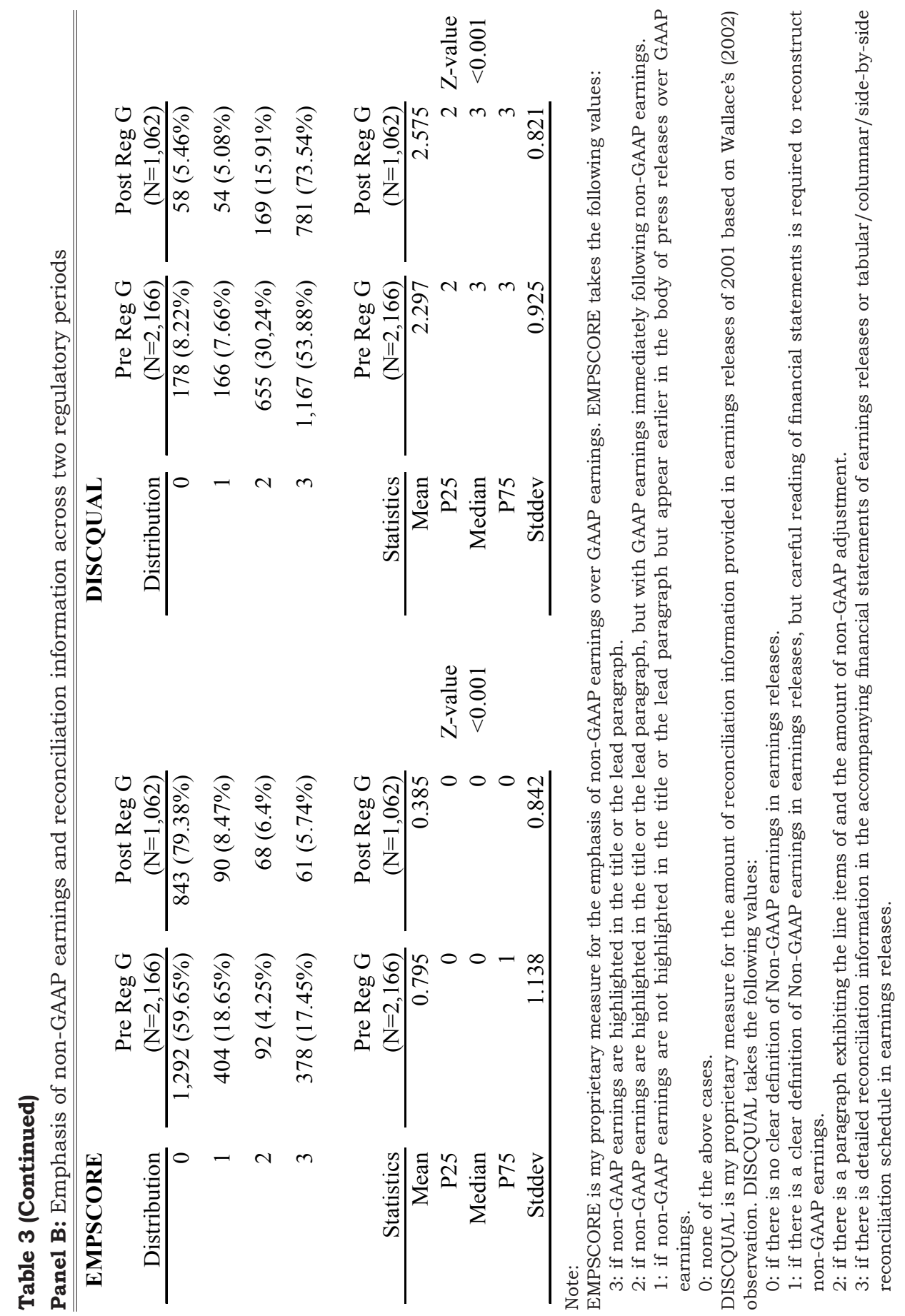


EPS and other EPSs vary across EPS definitions. This indicates that earnings adjusted by managers are not identical to earnings adjusted by other constituents (i.e., equity or credit analysts). Third, upward biases in non-GAAP earnings have decreased over time. Compared to GAAP EPS, the upward bias in non-GAAP earnings seems to have decreased over time (see the intersection of (f) and (h)/(i), p-values less than 0.01). However, I do not find a similar decrease regarding I/B/E/S Actual EPS and S\&P Core EPS (except the mean statistics in (e)/(h)). This raises the possibility that researchers can make an erroneous inference regarding the effect of Reg G when they restrict their sample firms to samples followed by specific constituents or screened by specific firm characteristics (e.g., highly capitalized firms).

Finally, panel B of table 3 provides descriptive statistics of various properties regarding non-GAAP earnings disclosures. EMPSCORE measures the emphasis placed on non-GAAP earnings (e.g., Bowen, Davis and Matsumoto 2005), coded from 3, where non-GAAP earnings was highlighted in the headline or in the lead paragraph of press releases over GAAP earnings, to 0 , where non-GAAP earnings are not emphasized at all. DISCQUAL, on the right hand section, measures the amount of reconciliation information provided in press releases (e.g., Zheng and Zhang 2005; Wallace 2002), coded from 3, where the firm provides a detailed pro-forma income statement or a tabular/columnar reconciliation table, to 0 , where there is no clear definition of non-GAAP earnings.

Panel B of table 3 suggests that firms are less likely to emphasize non-GAAP earnings in the post-Reg G period than in the pre-Reg G period ( $Z$-value $<0.001)$. Also, firms are more likely to provide detailed reconciliation information in the post-Reg G period than in the preReg $G$ period ( $Z$-value $<0.001)$. These results suggest that reporting firms have complied with Reg G requirements, improving the presentation quality of non-GAAP earnings in preliminary earnings announcements.

\section{EMPIRICAL TESTS AND RESULTS}

\section{Comparison of disclosure motives across time (H1 and H2)}

Research Design. To jointly test H1 and H2, I simultaneously run 
the following probit regression (1) for pre-Reg $G$ and post-Reg $G$ sample firm-quarters, and compare the coefficients and the marginal effects of two different disclosure motives across the time periods. ${ }^{11)}$ In this estimation, I also use firm-clustered standard errors to mitigate concerns about cross-sectional dependence in the residuals.

$$
\begin{aligned}
\text { Probability }(N G=1 \mid x)= & G\left(\beta_{0}+\beta_{1} E Q R A N K+\beta_{2} L O S S+\beta_{3} N E S\right. \\
& \left.+\beta_{4} \text { CONSENSUS }+\beta \cdot C O N T R O L S\right)
\end{aligned}
$$

(1), firm/quarter index omitted

The dependent variable is non-GAAP earnings disclosure, NG. The dichotomous variable, NG, is coded as 1 if managers voluntarily disclose non-GAAP earnings in preliminary earnings announcement press releases for a quarter, 0 otherwise.

EQRANK is an empirical proxy for the firm's communication motives to disclose non-GAAP earnings. EQRANK is a rank variable based on EQ, which is defined as the t-statistic on the coefficient of seasonally differenced GAAP earnings from the following firmspecific returns-GAAP earnings regression similar to Bradshaw and Sloan (2002) and Lougee and Marquardt (2004).

$$
M K T A D J R E T=a_{0}+a_{1} \triangle G A A P E A R N+\varepsilon
$$

(2), firm/quarter index omitted

\section{Where}

MKTADJRET is cumulative market adjusted returns (i.e., RET - VWRETD) from two days after the last quarterly earnings announcement to the day after the current quarter earnings announcement date, and

$\triangle G A A P E A R N$ is seasonally differenced GAAP earnings before extraordinary items and discontinued operations deflated by the market capitalization at the beginning of the current quarter (i.e., $\left[\left(\right.\right.$ COMPUSTAT Data25 $_{\mathrm{t}}-\left(\right.$ Data25 $\left.\left._{\mathrm{t}-4}\right)\right) /\left(\right.$ Data61 $_{\mathrm{t}}{ }^{*}$ Data17 $_{\mathrm{t}}^{*}$ Data14 $\left.\left.\left._{\mathrm{t}-1}\right)\right]\right)$.

11) This methodology helps better compare the coefficients across time without erroneous inferences from the interaction term (e.g, see Ai and Norton 2003, Norton, Wang and Ai 2004). 
This empirical proxy follows from the previous discussion of nonGAAP earnings as a supplement to less relevant GAAP earnings. If managers disclose non-GAAP earnings to communicate better when their GAAP earnings are less relevant (as documented in prior literature), I expect a negative association between NG and EQRANK (i.e., $\beta_{1}$ in equation (1) will be negative and significant). I rank firm specific t-statistics (EQ) from equation (2) by the calendar quarters in which preliminary earnings announcements were announced, assigning from 0 to 99 for EQRANK variable. Thus, EQRANK of 0 indicates the firm's GAAP earnings relevance is lowest among sample firms (i.e., suggesting these firms have higher incentives to communicate better with investors by disclosing non-GAAP earnings) while EQRANK of 99 indicates the firm's GAAP earnings relevance is highest among sample firms (i.e., suggesting these firms have lower incentives to disclose non-GAAP earnings). ${ }^{12)}$

LOSS, NES, and CONSENSUS are empirical proxies for the firm's opportunistic disclosure motives. LOSS, NES, and CONSENSUS are dichotomous variables and respectively coded as 1 if a firm has a GAAP loss, negative seasonally differenced GAAP EPS, or GAAP EPS falling short of the consensus EPS estimates, respectively, 0 otherwise. LOSS, NES, and CONSENSUS represent circumstances where firms may disclose non-GAAP earnings in order to mask poor GAAP earnings that fall short of various earnings benchmarks (Hirshleifer and Teoh 2003; Lougee and Marquardt 2004; Doyle, Jennings, and Soliman 2011). Thus, if managers disclose non-GAAP earnings to mask poor GAAP earnings performance falling short of various earnings benchmarks (i.e., opportunistic motives), I expect positive and significant associations between NG and LOSS, NES, and CONSENSUS, respectively (i.e., positive and significant $\beta_{2}, \beta_{3}$, and $\beta_{4}$ in equation (1)).

I also control for a vector of firm characteristics known to be associated with non-GAAP earnings disclosures and other voluntary disclosures. I include special items (SI, expected sign: -) because there often is a mechanical association between non-GAAP earnings and negative special items. I include the log of market capitalization $(\mathrm{LNMKT},+)$, the book to market ratio (BTM, -), the debt to asset ratio

12) I use t-statistics for $a_{1}$ in the equation rather than ERC $\left(a_{1}\right)$ or the adjusted $R^{2}$ of the equation because $t$-statistics parsimoniously combine the mean and variance of GAAP earnings informativeness in a single variable. 
Table 4. Descriptive statistics of firm characteristics by non-GAAP earnings disclosure and Reg $G$ regimes

Panel A: Descriptive statistics

\begin{tabular}{|c|c|c|c|c|c|c|c|c|}
\hline \multirow[b]{2}{*}{ Variables } & \multirow[b]{2}{*}{ Statistics } & \multirow[b]{2}{*}{$\begin{array}{c}\text { Predictions } \\
\text { (1) vs. (2) }\end{array}$} & \multicolumn{3}{|c|}{ Pre-Reg G period $(\mathrm{N}=5,405)$} & \multicolumn{3}{|c|}{ Post-Reg G period ( $\mathrm{N}=4,455)$} \\
\hline & & & $\begin{array}{r}\text { (1) Non-GAAP EPS } \\
\text { Disclosures Firms } \\
(\mathrm{N}=1,855) \\
\end{array}$ & $\begin{array}{r}\text { (2) No disclosures } \\
\text { Firms } \\
(\mathrm{N}=3,550) \\
\end{array}$ & P-values & $\begin{array}{r}\text { (1) Non-GAAP EPS } \\
\text { Disclosures Firms } \\
(\mathrm{N}=1,054) \\
\end{array}$ & $\begin{array}{r}\text { (2) No disclosures } \\
\text { Firms } \\
(\mathrm{N}=3,401) \\
\end{array}$ & P-values \\
\hline \multirow[t]{2}{*}{ EQ } & Mean & $<$ & 0.21 & 0.36 & $<.01$ & 0.14 & 0.45 & $<.01$ \\
\hline & Median & $<$ & 0.20 & 0.30 & $<.01$ & 0.12 & 0.37 & $<.01$ \\
\hline \multirow[t]{2}{*}{ EQRANK } & Mean & $<$ & 47.23 & 50.50 & $<.01$ & 44.39 & 51.24 & $<.01$ \\
\hline & Median & $<$ & 47.00 & 51.00 & $<.01$ & 42.00 & 51.00 & $<.01$ \\
\hline \multirow[t]{2}{*}{ LOSS } & Mean & $>$ & 0.37 & 0.22 & $<.01$ & 0.29 & 0.23 & $<.01$ \\
\hline & Median & $>$ & 0.00 & 0.00 & $<.01$ & 0.00 & 0.00 & $<.01$ \\
\hline \multirow[t]{2}{*}{ NES } & Mean & $>$ & 0.52 & 0.40 & $<.01$ & 0.41 & 0.35 & $<.01$ \\
\hline & Median & $>$ & 1.00 & 0.00 & $<.01$ & 0.00 & 0.00 & $<.01$ \\
\hline \multirow[t]{2}{*}{ CONSENSUS } & Mean & $>$ & 0.52 & 0.34 & $<.01$ & 0.53 & 0.33 & $<.01$ \\
\hline & Median & $>$ & 1.00 & 0.00 & $<01$ & 1.00 & 0.00 & $<.01$ \\
\hline \multirow[t]{2}{*}{ LNMKT } & Mean & $>$ & 6.48 & 5.54 & $<.01$ & 6.76 & 5.81 & $<.01$ \\
\hline & Median & $>$ & 6.46 & 5.61 & $<.01$ & 6.61 & 5.85 & $<.01$ \\
\hline \multirow{2}{*}{ LEVERAGE } & Mean & $>$ & 0.57 & 0.55 & $<.01$ & 0.59 & 0.55 & $<.01$ \\
\hline & Median & $>$ & 0.58 & 0.53 & $<.01$ & 0.60 & 0.53 & $<.01$ \\
\hline \multirow[t]{2}{*}{ BTM } & Mean & $>$ & 284.93 & 261.32 & 0.07 & 325.49 & 307.10 & 0.28 \\
\hline & Median & $>$ & 129.31 & 120.82 & 0.02 & 161.74 & 148.08 & $<.01$ \\
\hline \multirow[t]{2}{*}{ SI } & Mean & $<$ & -0.01 & 0.00 & $<.01$ & -0.01 & 0.00 & $<.01$ \\
\hline & Median & $<$ & 0.00 & 0.00 & $<.01$ & 0.00 & 0.00 & $<.01$ \\
\hline \multirow[t]{2}{*}{ HHI } & Mean & $<$ & 0.21 & 0.24 & $<.01$ & 0.23 & 0.26 & $<.01$ \\
\hline & Median & $<$ & 0.15 & 0.19 & $<.01$ & 0.17 & 0.20 & $<.01$ \\
\hline \multirow[t]{2}{*}{ INTANGIBLE } & Mean & $>$ & 0.09 & 0.06 & $<.01$ & 0.15 & 0.12 & $<.01$ \\
\hline & Median & $>$ & 0.00 & 0.00 & $<.01$ & 0.05 & 0.04 & $<.01$ \\
\hline \multirow[t]{2}{*}{ LITIGATIONIND } & Mean & $?$ & 0.24 & 0.18 & $<.01$ & 0.21 & 0.19 & 0.43 \\
\hline & Median & $?$ & 0.00 & 0.00 & $<.01$ & 0.00 & 0.00 & 0.43 \\
\hline \multirow[t]{2}{*}{ STDROA } & Mean & $>$ & 0.03 & 0.02 & $<.01$ & 0.02 & 0.02 & 0.61 \\
\hline & Median & $>$ & 0.01 & 0.01 & $<.01$ & 0.01 & 0.01 & 0.24 \\
\hline \multirow[t]{2}{*}{ HIGHTECH } & Mean & $>$ & 0.28 & 0.20 & $<.01$ & 0.23 & 0.42 & 0.33 \\
\hline & Median & $>$ & 0.00 & 0.00 & $<.01$ & 0.00 & 0.00 & $<.01$ \\
\hline \multirow[t]{2}{*}{ BIGBATH } & Mean & $<$ & 0.35 & 0.21 & $<.01$ & 0.27 & 0.22 & $<.01$ \\
\hline & Median & $<$ & 0.00 & 0.00 & $<.01$ & 0.00 & 0.00 & $<.01$ \\
\hline \multirow[t]{2}{*}{ 4THQTR } & Mean & $>$ & 0.25 & 0.24 & 0.48 & 0.19 & 0.20 & 0.26 \\
\hline & Median & $>$ & 0.00 & 0.00 & 0.21 & 0.00 & 0.00 & 0.14 \\
\hline \multirow[t]{2}{*}{ ROA } & Mean & $>$ & -0.01 & 0.00 & $<.01$ & 0.00 & 0.00 & 0.16 \\
\hline & Median & $>$ & 0.00 & 0.01 & $<.01$ & 0.00 & 0.01 & $<.01$ \\
\hline \multirow[t]{2}{*}{ PRIORNG } & Mean & $>$ & 0.76 & 0.13 & $<.01$ & 0.76 & 0.09 & $<.01$ \\
\hline & Median & $>$ & 1.00 & 1.00 & $<.01$ & 1.00 & 0.00 & $<.01$ \\
\hline
\end{tabular}

Note: See Appendix for the definition of variables.

(LEVERAGE, +), and the amount of intangible assets (INTANGIBLE, +) to capture the firm's overall voluntary disclosure environment. I include the Herfindahl-Hirschman Index (HHI, -) to capture the firm's propensity, if any, to conceal information due to competition. I include the dichotomous variable indicating high litigation indus- 


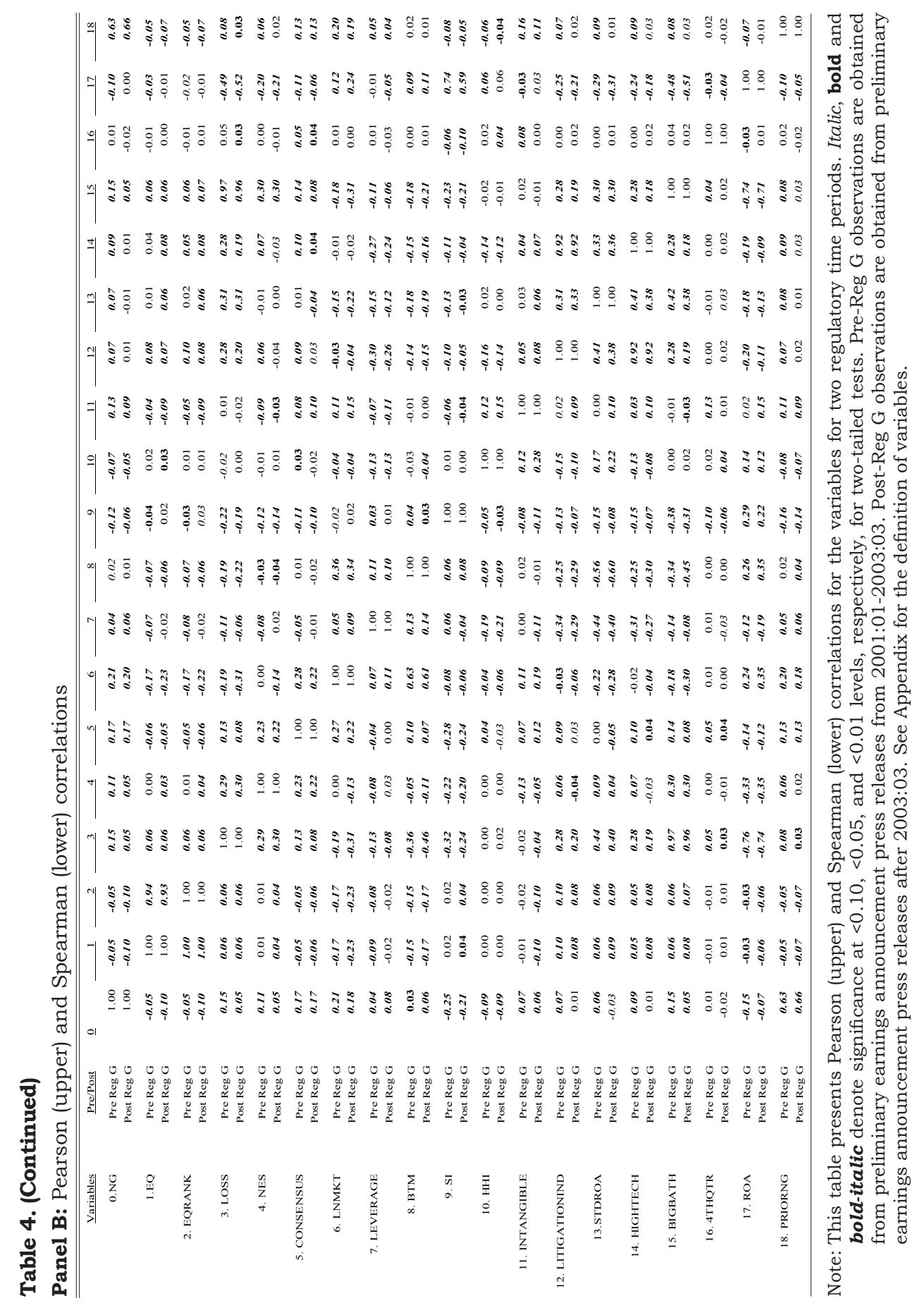


tries (LITIGATIONIND, ?) to capture the firm's propensity, if any, to avoid additional disclosure for litigation concerns. I also use the standard deviation of ROA (STDROA, +), tech industry membership (HIGHTECH, +), big bath taking (BIGBATH, -), the fourth quarter effect (4THQTR, +, Kinney and Trezevant 1997) from Heflin and Hsu (2005) and Marques (2006). Further, I control for firms' tendency to increase voluntary disclosure in good earnings periods (e.g., Miller 2002) by adding ROA (+). I finally control any omitted firm characteristics that could be captured in the firm's habitual tendency to disclose non-GAAP earnings ("ritualism" in Gibbins, Richardson, and Waterhouse 1990 or "habitual disclosures" in Graham et al. 2005) by including PRIORNG (+). PRIORNG is coded as 1 if there was non-GAAP disclosure in the prior quarter, 0 otherwise. See notes in panel A of table 4 for the definitions of these variables.

\section{Empirical results.}

Panels A and B of table 4 provide the univariate analyses of NG and disclosure motives and the correlations among variables respectively. These panels show that the associations between NG and communication motives (EQ, EQRANK) are stronger in the post Reg $\mathrm{G}$ period than in the pre Reg $\mathrm{G}$ period. In addition, both panels indicate that the associations between NG and two proxies for opportunistic motives (LOSS, NES) are weaker in the post Reg G period than in the pre Reg G period.

Panel A of table 5 provides the results from these multivariate probit regressions based on equation (1). Within each regression (column (A) and (B)), five control variables (SI, LEVERAGE, LNMKT, HHI, and PRIORNG) have the expected signs and are statistically significant. Column (A) of table 5 shows the association between NG and nonGAAP earnings disclosure motives in the pre-Reg $\mathrm{G}$ period. I do not find a significant negative association between NG and EQRANK in the pre-Reg G period (column (a), p-value 0.839). In contrast, I find evidence consistent with firms with opportunistic motives (LOSS, NES, and CONSENSUS) disclosing non-GAAP earnings in the preReg G period (column (a), p-values less than 0.01). The results in column (A) are consistent with firms primarily disclosing non-GAAP earnings for opportunistic but not communication motives in the less regulated environment (i.e., consistent with the critics' claim). Column (B) of table 5 shows the association between NG and disclosure motives in the post-Reg G period. I find a significant negative 


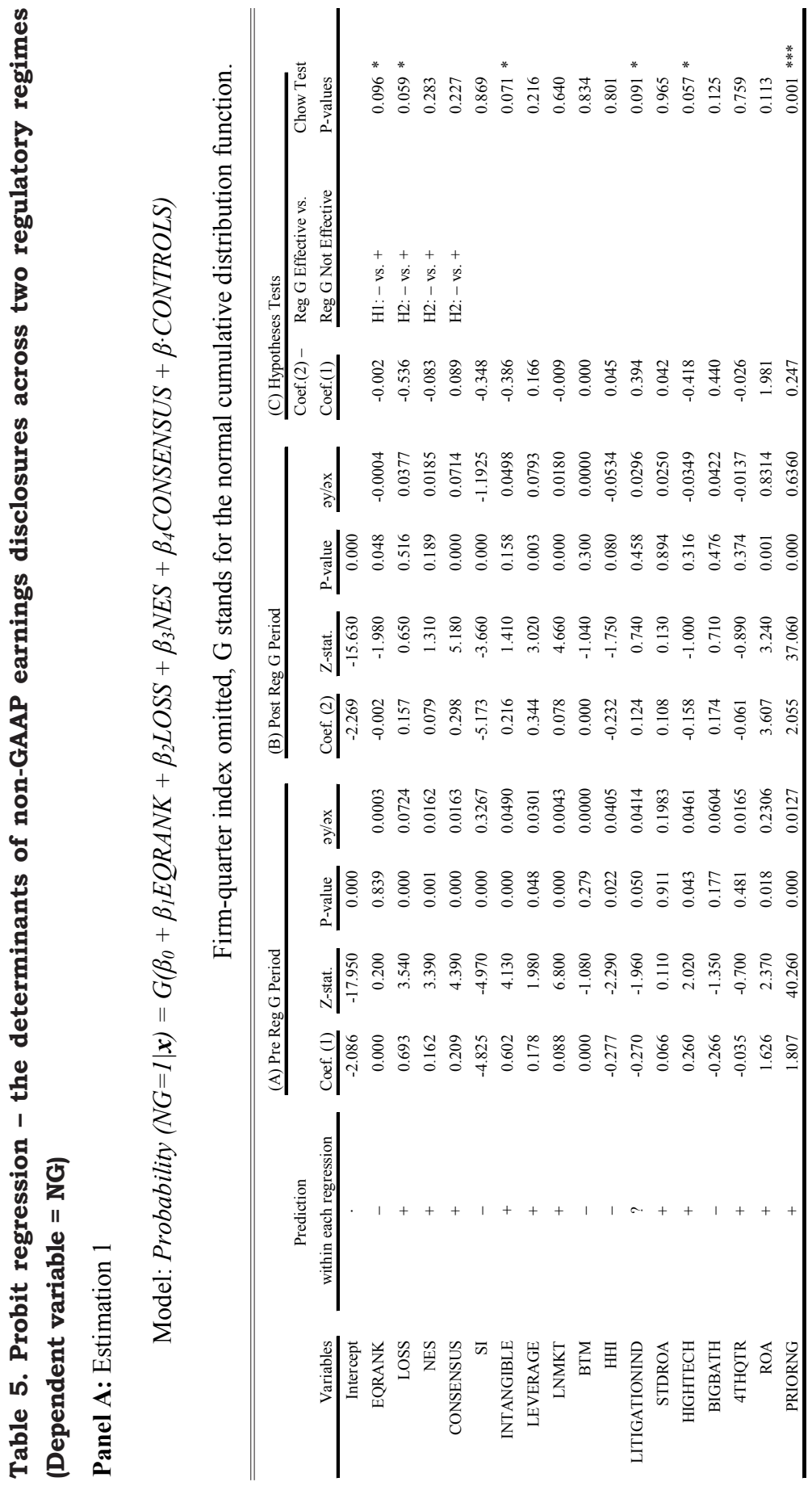

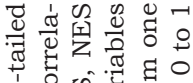

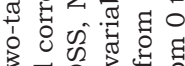
उ. 웅 웡 is 0 ,

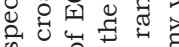

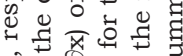
s.

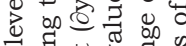
表 $\dot{v}$ 넝 $\checkmark$ 告 表 c⿻

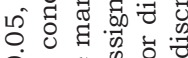
จ 0 o O

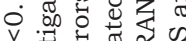

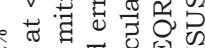

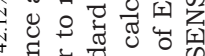
워

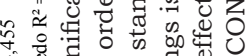

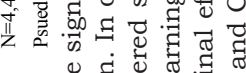

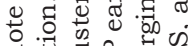

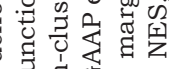
*

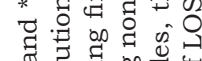
\% * E

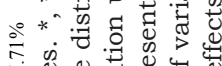
政 $\approx$ 零

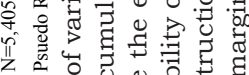

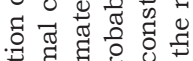

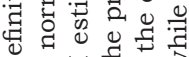
o

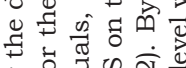

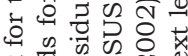
$\times$ 문

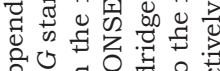

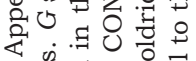

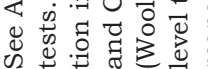
華 
association between NG and EQRANK, suggesting that firms with communication motives disclose non-GAAP earnings in the post-Reg $\mathrm{G}$ period $(\mathrm{P}$-value $=0.048)$. While I also find a significant positive association between NG and CONSENSUS, I do not find such associations between NG and LOSS/NES in the post-Reg G period (p-values 0.516 and 0.189 respectively).

In order to assess whether Reg $G$ affects the magnitude of these associations over time ( $\mathrm{H} 1$ and $\mathrm{H} 2$ ), I compare the coefficients of disclosure motive variables across the two time periods $\left(\mathrm{x}^{2}\right.$ statistic from the Chow test in column (C)). The coefficient difference of EQRANK across time is positive and marginally significant ( $p$-value $=0.096)$, suggesting that the propensity of firms to disclose non-GAAP earnings for better communication has increased over time. Specifically, compared to firms at the top of EQRANK, firms at the bottom of EQRANK (i.e., higher communication motives) in the post-Reg G period are about seven percent more likely to disclose non-GAAP earnings than in the pre-Reg G period. In parallel, the positive association between NG and LOSS is lessened in the post-Reg G period ( $\mathrm{p}$-value=0.059), suggesting that compared to profit firms, LOSS firms in the post-Reg G period are less likely to disclose non-GAAP earnings than LOSS firms in the pre-Reg G period. Similarly, while NES firms in the pre-Reg G period are more likely to disclose non-GAAP earnings, this tendency no longer exists in the post-Reg G period (see column (B), p-value=0.185). However, the coefficient difference across two time periods is not statistically different. The results regarding LOSS and NES suggest that opportunistic non-GAAP earnings disclosures appear to have decreased over time. I do not find similar evidence on the association between NG and CONSENSUS. ${ }^{13)}$ Taken together, these results imply that decreased disclosure of non-GAAP earnings post Reg G is more pronounced for firms with opportunistic motives than for firms with communication motives.

To further mitigate the concern that the cross-sectional dependence in the residuals may affect my estimations for (1) due to habitual pro-forma disclosing firms, I run the following random effect model (1a) with a dummy variable (Wooldridge 2002, Ch.15). ${ }^{14}$

13) Descriptive statistics show that the frequency of disclosed non-GAAP earnings that actually meet or slightly beat the consensus EPS by up to 2 cents has decreased over time (4.53\% difference, $\mathrm{p}$-value $=0.046$, untabulated).

14) One caveat of this approach is that we cannot simply translate the coefficient of 


\section{Table 5/ (Continued)}

Panel B: Estimation 2

$$
\begin{aligned}
& \text { Probability }(N G=1 \mid \boldsymbol{x}) \\
& =G\left(\beta_{0}+\beta_{1} E Q R A N K+\beta_{2} L O S S+\beta_{3} N E S+\beta_{4} \text { CONSENSUS }+\beta \cdot C O N T R O L S+\beta_{5} P O S T\right. \\
& +\beta_{6} E Q R A N K^{*} P O S T+\beta_{7} \text { LOSS } * \text { POST }+\beta_{8} N E S^{*} P O S T+\beta_{9} \text { CONSENSUS } * \text { POST } \\
& +\beta \cdot C O N T R O L S^{*} P O S T \text { ) (firm/quarter index omitted) }
\end{aligned}
$$

\begin{tabular}{|c|c|c|c|}
\hline Varaibles & Coefficient & Z Stat. & P-Values \\
\hline INTERCEPT & -2.549 & -13.790 & $0.000 * * *$ \\
\hline EQRANK & 0.000 & -0.390 & 0.694 \\
\hline LOSS & 0.895 & 3.860 & $0.000 * * *$ \\
\hline NES & 0.161 & 2.850 & $0.004 * * *$ \\
\hline CONSENSUS & 0.232 & 4.110 & $0.000 * * *$ \\
\hline SI & -5.084 & -4.470 & $0.000 * * *$ \\
\hline INTANGIBLE & 0.600 & 3.080 & $0.002 * * *$ \\
\hline LEVERAGE & 0.218 & 1.480 & 0.139 \\
\hline LNMKT & 0.173 & 8.370 & $0.000 * * *$ \\
\hline BTM & 0.000 & -1.780 & $0.074 *$ \\
\hline HHI & -0.339 & -1.680 & $0.093 *$ \\
\hline LITIGATIONRISK & -0.252 & -1.000 & 0.315 \\
\hline STDROA & 0.429 & 0.510 & 0.613 \\
\hline HIGHTECH & 0.339 & 1.440 & 0.149 \\
\hline BIGBATH & -0.346 & -1.500 & 0.133 \\
\hline 4THQTR & -0.046 & -0.830 & 0.404 \\
\hline ROA & 1.502 & 1.750 & $0.080 *$ \\
\hline PRIORNG & 1.230 & 20.880 & $0.000 * * *$ \\
\hline POST & -0.296 & -1.720 & $0.086 *$ \\
\hline EQRANK*POST & -0.003 & -2.260 & $0.024 * *$ \\
\hline LOSS*POST & -0.660 & -1.770 & $0.077 *$ \\
\hline NES*POST & -0.104 & -1.140 & 0.253 \\
\hline CONSENSUS*POST & 0.126 & 1.490 & 0.135 \\
\hline SI*POST & -1.497 & -0.770 & 0.443 \\
\hline INTANGIBLE*POST & -0.630 & -2.620 & $0.009 * * *$ \\
\hline LEVERAGE*POST & 0.222 & 1.340 & 0.181 \\
\hline LNMKT*POST & 0.159 & 1.190 & 0.234 \\
\hline BTM*POST & 0.000 & -0.990 & 0.322 \\
\hline HHI ${ }^{*} \mathrm{POST}$ & 0.035 & 0.170 & 0.867 \\
\hline LITIGATIONIND*POST & 0.449 & 1.860 & $0.063 *$ \\
\hline STDROA*POST & -0.446 & -0.370 & 0.715 \\
\hline HIGHTECH*POST & -0.524 & -2.320 & $0.020 * *$ \\
\hline BIGBATH*POST & 0.616 & 1.640 & 0.101 \\
\hline 4THQTR*POST & -0.011 & -0.110 & 0.911 \\
\hline ROA*POST & 3.068 & 2.000 & $0.046 * *$ \\
\hline PRIORNG*POST & 0.244 & 3.410 & $0.001 * * *$ \\
\hline
\end{tabular}

Number of Observations: 9,860

Psuedo R Square: $40.23 \%$

Note: In order to further mitigate the cross-sectional correlation in the residuals, the results are presented based on the estimation by a random effect probit model (Gaussian assumption) with firm-clustered standard errors. Pseudo $\mathrm{R}^{2}$ is calculated by scaling the log-likelihood value of the equation with the log likelihood of the constant-only model. For the definition of variables, see Appendix. ${ }^{*}{ }^{* *}$ and ${ }^{* * *}$ denote significance at $<0.10$, $<0.05$, and $<0.01$ levels, respectively, for two-tailed tests. 


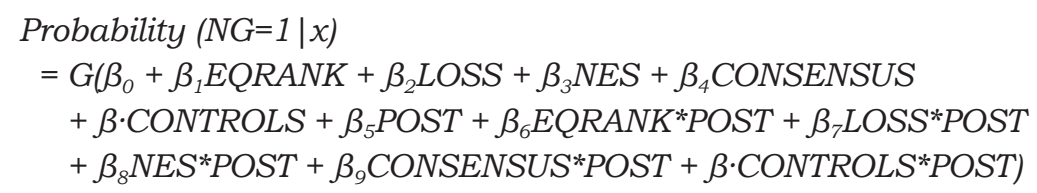

(1a), firm/quarter index omitted

POST is an indicator variable coded as 1 if the firm releases nonGAAP earnings disclosures after March 23 of 2003, 0 otherwise.

Panel $\mathrm{B}$ of table 5 presents the estimation of this regression. The coefficients on two interaction terms (EQRANK*POST, LOSS*POST) are negative and statistically significant at 0.024 and 0.077 levels. Also, the coefficient on NES is not significant in the post Reg G period (i.e., NES + NES*POST, at p-value $=0.17$, untabulated). Thus, the results from this alternative estimation do not change my inferences.

\section{Comparison of the market's perception of non-GAAP earnings (H3)}

Research design.

Assessing whether investors' perceptions of the transparency of non-GAAP earnings disclosures are consistent with inferences drawn from the change in managers' disclosure motives, I run an OLS regression of three-day size adjusted cumulative returns on both non-GAAP earnings surprises and GAAP earnings surprises after controlling for known covariates (i.e., book-to-market ratio, loss, ROA), with the post-Reg G dummy (equation (3)). Note that the sample in this test is restricted to firms that provide both seasonally differenced GAAP and non-GAAP earnings surprises to follow the specification suggestion made in Bradshaw (2003).

$$
\begin{aligned}
\text { SADJRET }=\gamma_{0} & +\gamma_{1} U E_{-} G A A P+\gamma_{2} U E_{-} \text {NONGAAP }+\gamma_{3} L O S S+\gamma_{4} B T M+\gamma_{5} R O A+\gamma_{6} P O S T \\
& +\gamma_{7} U E_{-} G A A P * P O S T+\gamma_{8} U E_{-} N O N G A A P * P O S T+\gamma_{9} L O S S * P O S T \\
& +{ }_{10} B T M * P O S T+\gamma_{11} R O A * P O S T+\varepsilon
\end{aligned}
$$

where

(3), firm/quarter index omitted SADJRET is cumulative abnormal returns, defined as the sum of size adjusted daily returns over the three-day window $(-1,0,+1)$, 
where 0 is the date of the preliminary earnings announcement press release. Note that the size factor for returns is implicitly controlled by size-adjusted returns. $\left.{ }^{15}\right)$

UE_GAAP (UE_NONGAAP) is seasonally differenced quarterly GAAP (non-GAAP) earnings deflated by the market capitalization at the beginning of the current fiscal quarter adjusted by stock splits factor.

POST is an indicator variable coded as 1 if the earnings announcement date for a fiscal quarter is after March 2003, 0 otherwise.

LOSS is an indicator variable coded as 1 if GAAP earnings is negative, otherwise 0 .

$B T M$ is the book to market ratio capturing growth factor.

$R O A$ is the return on assets.

If Reg $\mathrm{G}$ has discouraged firms with opportunistic disclosure motives from providing non-GAAP earnings disclosures and reconciliation information helps investors better appreciate the information content of non-GAAP earnings post-Reg G, I expect a positive association between SADJRET and UE_NONGAAP, and I expect it to be stronger in the post-Reg G period than in the pre-Reg $G$ period (i.e., $\gamma_{8}>0$ ). If Reg $G$ has discouraged firms with communication motives from presenting non-GAAP earnings disclosures and reconciliation information helps investors better discern managers' strategic motives post-Reg G, I expect the positive association between SADJRET and UE_NONGAAP to be weaker in the post-Reg G period than in the pre-Reg G period (i.e., $\gamma_{8}<0$ ). Alternatively, if Reg G has discouraged firms with both opportunistic and communication motives relating to non-GAAP earnings disclosures, I do not expect the assumed positive association between SADJRET and UE_NONGAAP to be statistically different across the pre- and the post-Reg $G$ periods (i.e., $\gamma_{8}=0$ ).

Empirical results.

Panel A of table 6 presents the results of OLS regression of equa-

15) In most cases, firms release $8-\mathrm{K}$ with non-GAAP reconciliation information on the earnings announcement date or on the following date. Thus, three day window is likely to capture investors' response to both non-GAAP earnings and reconciliation information. See the robustness check section for the details for the $8-\mathrm{K}$ release statistics. 


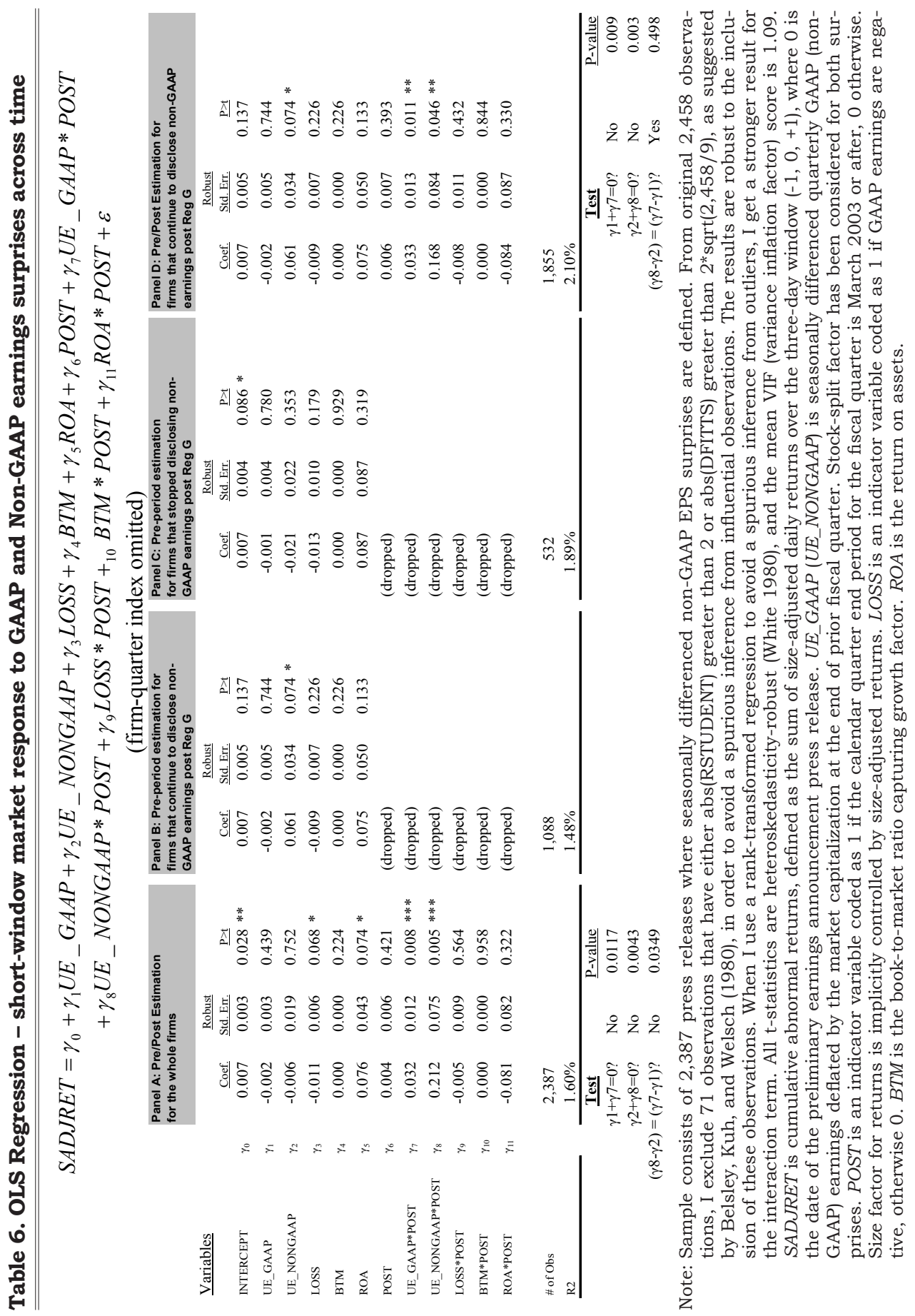


tion (3). The coefficient on GAAP earnings surprises (UE_GAAP) is positive in the pre-Reg $G$ period, but not statistically significant ( $P$ value $=0.439$ ). This is not surprising because firms that disclose nonGAAP earnings are likely to exhibit low GAAP earnings relevance. In contrast to the results from prior studies that reported incremental information content of non-GAAP earnings over GAAP earnings in the years preceding my sample period, however, there is no incremental information content of non-GAAP earnings over GAAP earnings in the pre-Reg G period (2001:01-2003:03, UE_NONGAAP, $\mathrm{P}$-value $=0.752$ ). Thus, the result in the pre Reg $\mathrm{G}$ period appears consistent with the SEC's and the critics' allegations that many firms disclosed misleading or value-irrelevant non-GAAP earnings prior to the regulatory intervention period.

On the other hand, the coefficients on both UE_GAAP $\left(\gamma_{1}+\gamma_{7}\right.$, p-value $=0.012)$ and UE_NONGAAP $\left(\gamma_{2}+\gamma_{8}, p\right.$-value $\left.=0.004\right)$ in the post-Reg $G$ period are positive and significant, suggesting both GAAP earnings and non-GAAP earnings are priced in the post Reg $\mathrm{G}$ period. The interaction term of POST and UE_GAAP $\left(\gamma_{7}\right)$ is positive and significant at the 0.008 level, indicating that the information content of GAAP earnings surprises in the post-Reg G period increases. This may indicate that the relative weights placed on GAAP earnings by market participants has increased over time due to explicit GAAP presentation requirement in Reg G. In addition, the variable of interest in this study, POST $U E \_N O N G A A P\left(\gamma_{8}\right)$, is positive and significant ( $\mathrm{p}$-value $=0.005)$. This suggests that the information content of non-GAAP earnings surprises in the post-Reg G period also increases, possibly due to increased reconciliation information provided by Reg G.

Some may question why the incremental information content of non-GAAP earnings in the pre-Reg G period is not significant. Note that while the sample period of prior studies reporting the incremental information content of actual non-GAAP earnings covers years preceding 2001, my study covers the period of 2001 and 2002, years following recent corporate scandals. Therefore, I believe there are two possible reasons for the difference between my findings and those of prior studies: (1) investors perceived that firms were disclosing non-GAAP earnings for opportunistic motives prior to Reg G because some firms indeed disclosed non-GAAP earnings opportunistically as the critics argued and/or (2) investors could not discern the disclosure motives but were so skeptical about the 
information content of all non-GAAP earnings that they undervalued non-GAAP earnings disclosures provided for either reason.

In order to further investigate this issue, I run equation (3) for two sub-sets of firms, one sub-set that discontinued disclosing non-GAAP earnings in the post Reg G period, and another subset that continued non-GAAP earnings disclosures. Based on the results from $\mathrm{H} 1$ and $\mathrm{H} 2$, I assume that firms that discontinued disclosing non-GAAP earnings were likely non-GAAP manipulators. Similarly, I assume that firms that continued non-GAAP earnings disclosures were likely communicators. If no evidence of non-GAAP earnings relevance in my pre Reg $G$ sample firm-quarters $\left(\gamma_{2}\right.$ in column (A)) was due to some opportunistic firms in less regulated environment and the market could see through the managerial motives, no evidence of non-GAAP earnings' informativeness in the pre Reg G period could be only found for sub-sample of firms that discontinued disclosing non-GAAP earnings in the post Reg G period (likely opportunistic firms). Alternatively, if the market was not efficient and investors could not discern disclosure motives, no evidence of non-GAAP earnings' informativeness in the pre Reg G period should be found for both sub-samples.

Panel B of table 6 suggests that firms that disclosed non-GAAP earnings in both the pre- and post-Reg G periods (i.e., communicators) indeed exhibit the incremental information content of nonGAAP earnings even in the pre-Reg G period (i.e., positive and significant $\gamma_{2}$. in panel $\mathrm{B}, \mathrm{p}$-value $=0.074$ ). When I estimate the equation for the firms that discontinued disclosing non-GAAP earnings in the post-Reg G period for their pre-Reg G observations (panel C of table $6)$, however, I do not find the informativeness of non-GAAP earnings. The results in panel $\mathrm{D}$ of table 6 , the pre and post estimation for firms that disclose non-GAAP earnings in both periods, further suggest that the results in panel A of table 6 are likely due to the fact that firms that had noisy non-GAAP earnings (i.e., column $\mathrm{C}$ firms) had dropped their non-GAAP earnings disclosures in the post-Reg G period. These results indicate that the information content of nonGAAP earnings in the post-Reg $\mathrm{G}$ in my sample might be low due to opportunistic non-GAAP earnings disclosing firms and that the market could see through disclosure motives.

Other issues in table 6 are why the coefficients of both GAAP and non-GAAP earnings increase in the post Reg G period and whether these increases may imply other contemporaneous changes rather 
than the Reg G effect. The bottom of panel A of table 6 indicates that combined coefficients of the pre- and post-UE_GAAP (i.e., $\gamma_{1}+\gamma_{7}$ ) and UE_NONGAAP (i.e., $\gamma_{2}+\gamma_{8}$ ) are statistically different from zero. In addition, the information content change of non-GAAP earnings over the two periods (i.e., $\gamma_{8}-\gamma_{2}$ ) is greater than that of GAAP earnings (i.e., $\left.\gamma_{7}-\gamma_{1}\right)$ (p-value of 0.0349), suggesting that the significant and positive $\gamma_{8}$ is not merely the manifestation of a contemporaneous factor associated with both GAAP and non-GAAP EPS.

Overall, the results presented in table 6 are consistent with the idea that investors are more likely to value the information content of non-GAAP earnings in the post-Reg G period than they did in the pre-Reg G period. Assuming the market efficiency, I interpret those results as evidence consistent with the idea that Reg G affects managers' disclosure motives and causes them to stop disclosing less relevant non-GAAP earnings in the post Reg G period, and investors concurrently view non-GAAP earnings as more transparent post Reg $G$ than they did previous to Reg G. Also, investors appear to place weights on GAAP earnings post Reg G possibly due to the increased reconciliation between non-GAAP earnings and GAAP earnings.

\section{Comparison of the quality of income-increasing non-GAAP adjustments over time (H4 and H5)}

\section{Research design.}

Prior research suggest that if income increasing non-GAAP earnings are misleading investors or are non-transitory, those income increasing non-GAAP adjustments would be associated with negative future returns or future operating income. Consistent with this idea, Doyle, Lundholm, and Soliman (2003) and Frankel, McVay and Soliman (2011) document the negative associations between income increasing non-GAAP adjustments and future returns/future operating income.

To test whether the extent to which "pro-forma earnings-hype" mislead investors has changed over time (H4), I regress one year value-weighted size, book-to-market, momentum adjusted buy and hold abnormal returns on income-increasing non-GAAP earnings adjustments, allowing the relation to vary across time (equation (5)). In testing $\mathrm{H} 4$, I focus on income increasing non-GAAP earnings disclosure because (1) regulators' and critics' concerns were primarily for income increasing non-GAAP adjustments and (2) there is no 
clear theoretical link between income-decreasing non-GAAP earnings and future performance indicators for inferences. ${ }^{16)}$ In estimating (5), I do not exclude outliers because data trimming in a longrun performance test may produce a spurious conclusion (Kothari, Sabino, and Zach 2005). ${ }^{17}$

$$
\text { VBHAR }=\gamma_{0}+\gamma_{1} U P A D J+\gamma_{2} P O S T+\gamma_{3} U P A D J * P O S T+\varepsilon
$$

where

(5), firm-quarter index omitted

VBHAR is one year value-weighted size, book-to-market, momentum adjusted buy and hold abnormal returns for each firm $i$ and quarter $t$ as in Daniel et al. (1997), defined as

$$
\left[\prod_{t=1}^{12}\left(1+R E T_{i t}\right)\right]-\sum_{j=1}^{N_{\mathrm{SBM} \text { decile }}} \omega_{j}\left[\prod_{t=1}^{12}\left(1+R E T_{j t}\right)\right]
$$

where

$t=$ time (month) index starting at the month after earnings announcement month,

$i=$ firm index, $R E T$ is monthly return from CRSP,

$j=$ firm index in a size, book to market, and momentum decile in which the firm in the earnings announcement month falls,

$N_{\text {SBM_decile }}=$ the number of firms in the size, book to market, and momentum decile in which the firm in the earnings announcement month falls,

$\omega_{j}=$ the market capitalization weight at the beginning of compo unding (month after earnings announcement month)),

$U P A D J$ is income-increasing non-GAAP earnings adjustment per share deflated by total assets, and

$P O S T$ is an indicator variable coded as 1 if the calendar quarter end period for a fiscal quarter is March 2003 or after, 0 otherwise.

To test whether the extent to which the non-transitory nature of "income-increasing " non-GAAP adjustments (i.e., possible misleading non-GAAP adjustments) has changed over time, I regress future operating income on income-increasing non-GAAP earnings

16) For example, one cannot conclude that managers mislead investors with their non-GAAP earnings disclosures when she finds a negative association between income decreasing non-GAAP earnings and positive future returns.

17) All results are robust to exclusion of outliers, though. 
adjustments across time (H5, equation (6)). Due to similar reasons addressed in equation (5), I focus on income-increasing non-GAAP adjustments and report the estimation of (6) without trimming outliers. ${ }^{18)}$ I borrow both the idea and the specification of this test from Frankel, McVay and Soliman (2011). Their idea is that transparent income-increasing non-GAAP adjustments are likely to be transitory by nature while misleading income-increasing non-GAAP adjustments are likely to be permanent (i.e., negative association between "exclusion" and future performance).

$$
\begin{aligned}
\text { FUTUREOPINC } & =\gamma_{0}+\gamma_{1} \text { NONGAAPEPS }+\gamma_{2} \text { UPADJ } 2+\gamma_{3} L N M K T \\
& +\gamma_{4} \text { SALESGROWTH }+\gamma_{5} \text { LOSS }+\gamma_{6} S T D R O A \\
& +\gamma_{7} P O S T+\gamma_{8} N O N G A A P E P S * P O S T+\gamma_{9} U P A D J 2 * P O S T \\
& +\gamma_{10} L N M K T * P O S T+\gamma_{11} \text { SALESGROWTH *POST } \\
& +\gamma_{12} L O S S * P O S T+\gamma_{13} \text { STDROA * POST }+\varepsilon
\end{aligned}
$$

where

(6), firm-quarter index omitted FUTUREOPINC is four quarters ahead operating income per share, NONGAAPEPS (expected sign +) is non-GAAP earnings per share, UPADJ2 ( - if non-GAAP earnings are not transitory) is incomeincreasing non-GAAP earnings adjustment per share (not deflated to make this variable similar to the "exclusion" variable in Frankel et al. 2005), ${ }^{19)}$

$\operatorname{LNMKT}(+)$ is the log of market values,

SALESGROWTH $(+)$ is the current sales minus prior sales divided by prior sales,

LOSS (-) is an indicator variable coded as 1 if GAAP earnings is negative, otherwise 0 ,

STDROA (-) is the standard deviation of ROA from prior eight quarters.

\section{Empirical Results.}

Table 7 presents the result of estimating equation (5) (H4). Consistent with prior findings (e.g., Doyle, Lundholm, and Soliman 2003), panel A of table 7 suggests that the negative association between income-increasing non-GAAP adjustment and abnormal returns exists in the pre Reg G period ( $\gamma_{1}$ in panel A of table $7, p$-value $=0.065$ ).

18) All results are robust to exclusion of outliers, though.

19) The results are robust to price and sales deflators, though. 


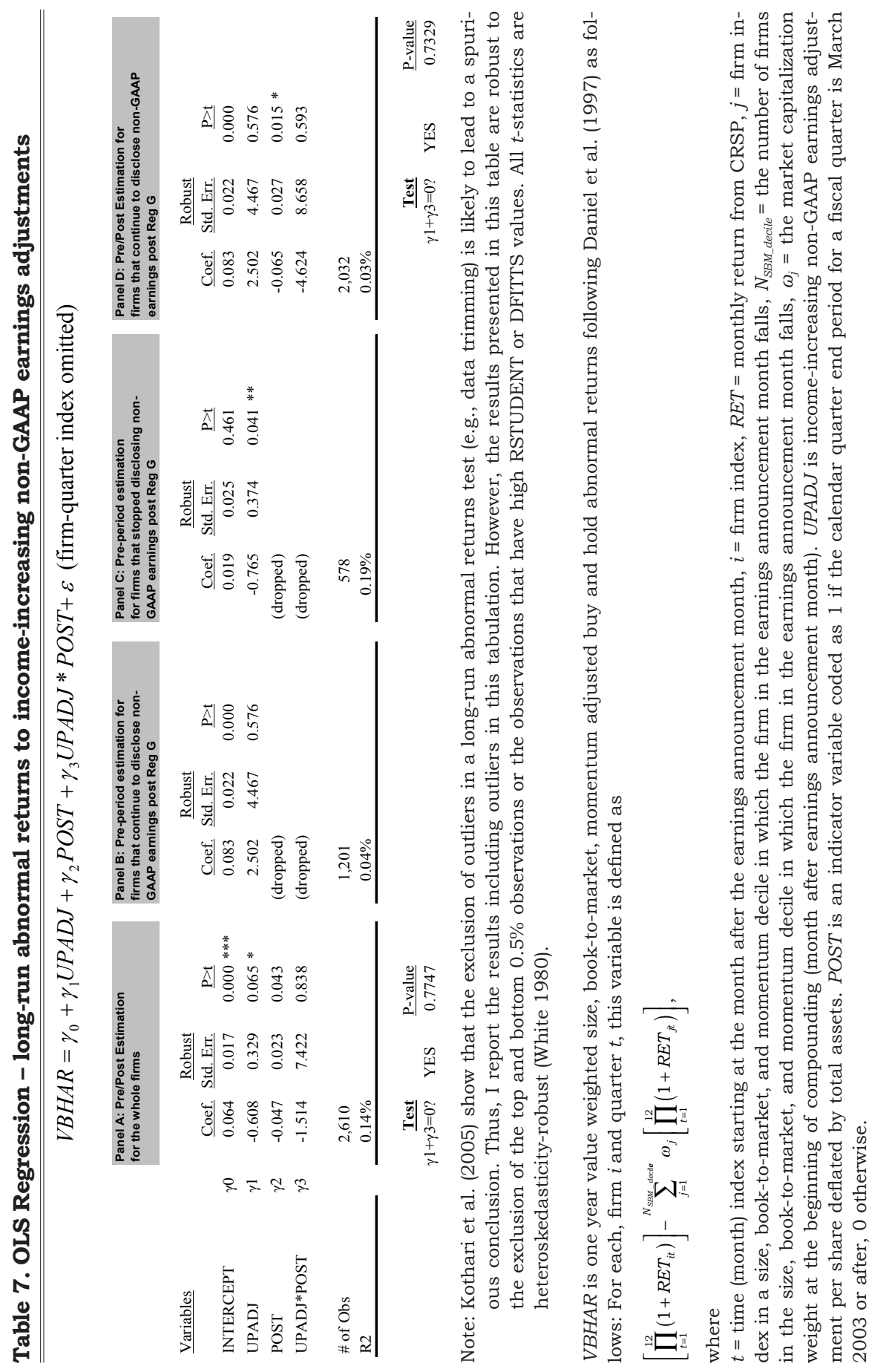


However, it appears that the tendency is no longer evident in the post Reg $G$ period (i.e., the test of $\gamma_{1}+\gamma_{3}=0$, p-value $=0.774$ ).

In order to further investigate whether the decreased negative association is due to the decrease of misleading non-GAAP earnings disclosures, I estimate equation (5) by partitioning my sample firms in a manner similar to that shown in table 6: firms that continue to provide non-GAAP earnings post Reg G (panel B) vs. firms that stopped disclosing non-GAAP earnings post Reg G (panel C). Panel $B$ of table 7 shows that the negative association in the pre-Reg G period in panel $\mathrm{A}$ is not pronounced by firms that continued to provide non-GAAP earnings post Reg G (i.e., likely transparent firms from the results of $\mathrm{H} 1$ and $\mathrm{H} 2$ ). In contrast, panel $\mathrm{C}$ of table 7 indicates that the negative association in the pre Reg G-period is indeed manifested by firms that stopped disclosing non-GAAP earnings post Reg G (i.e., negative $\gamma_{1}$ in panel $\mathrm{C}$, p-value $=0.041$ ). Accordingly, the negative association is not observed for both periods for firms that continue to disclose non-GAAP earnings in the post-Reg G period (see panel D of table 7). The results presented in table 7 (i.e., H4) are consistent with the idea that there were firms that disclosed lessrelevant non-GAAP earnings in the pre-Reg G period and Reg G has discouraged these firms from disclosing non-GAAP earnings post Reg $\mathrm{G}^{20)}$

Table 8 presents the estimation of equation (6) (H5). Panel A of table 8 shows that the negative association between income-increasing non-GAAP adjustment and four quarters ahead future operating income exists in the pre Reg G period ( $\gamma_{2}$ in panel A of table 8 , pvalue $=0.00$ ) as documented in Frankel, McVay, and Soliman (2011). Other control variables are all significant as expected except SALESGROWTH. In contrast, it appears that the tendency is no longer evident in the post Reg G period (i.e., $\gamma_{2}+\gamma_{9}$ is not different from zero, $\mathrm{p}$-value $=0.132$ ).

In order to further investigate whether the decreased negative association is due to the decrease of non-transitory non-GAAP adjustments, I estimate the model (6) by partitioning my sample firms similar to table 6 and 7: firms that continue to provide non-GAAP earnings post Reg G (panel B) vs. firms that stopped disclosing nonGAAP earnings post Reg G (panel C). Panels B and C of table 8

20) In untabulated results, I find that the inferences presented in table 7 were not sensitive to alternative deflators for non-GAAP adjustments (i.e., sales, prices). 


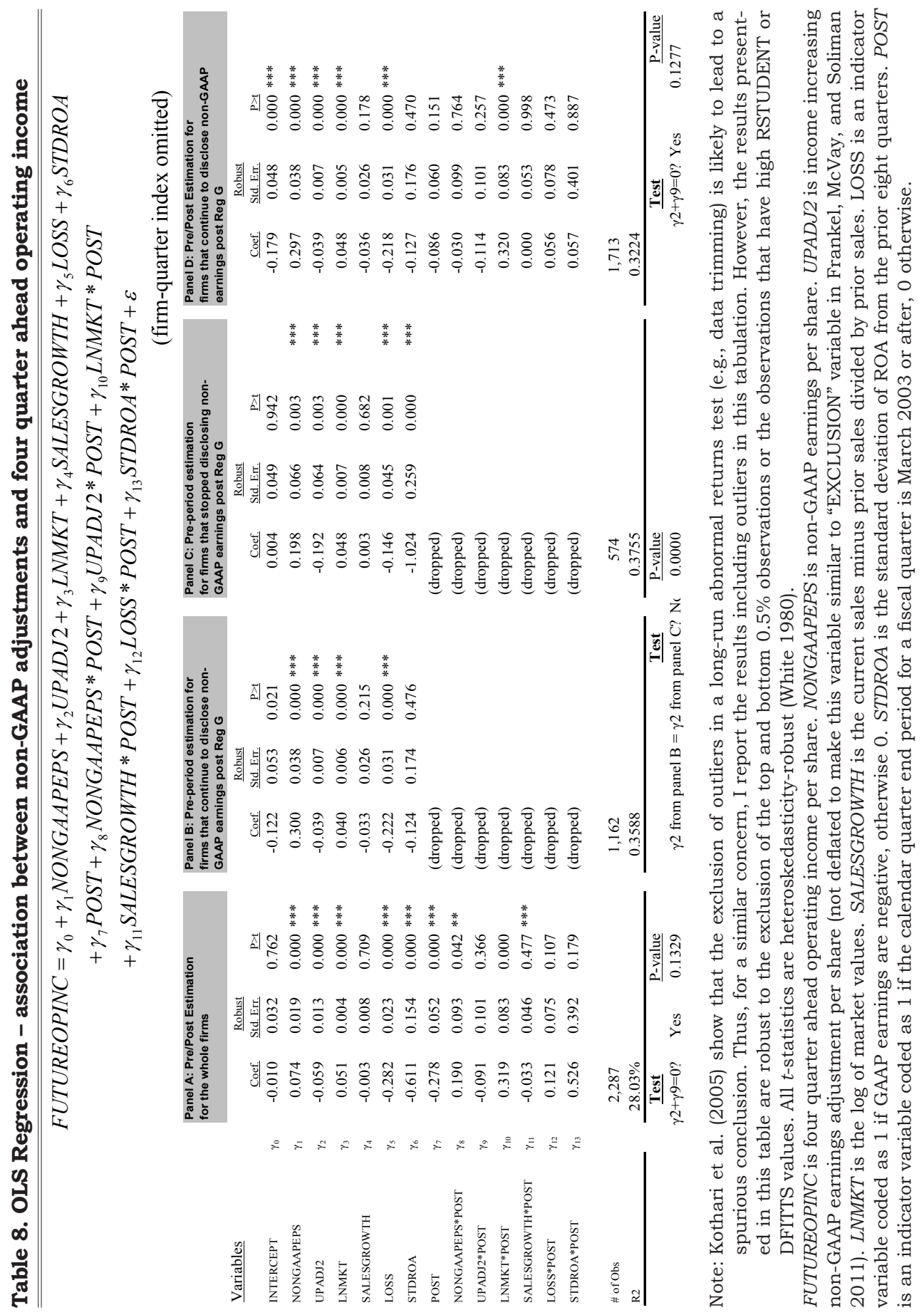


suggest that the negative association in the pre Reg G-period is observed for both firms. However, the coefficient in the column B (i.e., likely transparent firms based on the results from $\mathrm{H} 1$ and $\mathrm{H} 2$ ) are much lower than the coefficient in the column $\mathrm{C}$ (i.e., $\gamma_{2}$ in panel $\mathrm{B}$ is smaller than $\gamma_{2}$ in panel $\mathrm{C}, \mathrm{p}$-value $=0.00$ ). This is consistent with the idea that non-GAAP adjustments made by continuously disclosing firms are more transitory (i.e., transparent) than those made by firms that stopped disclosing non-GAAP earnings post Reg G. Panel $D$ also provides evidence confirming that more transitory non-GAAP adjustments in the post Reg G (panel A) are driven by firms that continued to disclose non-GAAP earnings. The results presented in table 8 (i.e., H5) are consistent with the idea that there were firms that disclosed less transitory non-GAAP adjustments in the pre-Reg $G$ period and Reg $G$ has discouraged these firms from disclosing non-GAAP earnings post Reg G. One caveat for testing H4 and H5 should be noted. That is, we cannot completely rule out the possibility that the results are due to the smaller number of post-Reg G observations and the related test power issue. ${ }^{21)}$

\section{Robustness Check}

Alternative Sub-Sample Periods.

Given the SEC warning in December 2001 (see footnote 3 for institutional details), there might have been pre-empting effects in the period after the SEC warning and before Reg G. In order to address these issues, I ran equations (1) though (6) for the two sub periods prior to Regulation G (before and after the SEC-issued cautionary advice). I do not find that the SEC warning caused pre-empting effects in untabulated results.

\section{Alternative measures for EQRANK.}

My inferences are unaffected by replacing EQRANK with EQ, ERC, the rank of ERC, $\mathrm{R}^{2}$, or the rank of $\mathrm{R}^{2}$ and EQRANK estimations solely from the pre and the post Reg G observations. I also use a hybrid EQRANK measure, where EQRANK measures in the pre- and the post-Reg G periods have single values from time-series estima-

21) All inferences from table 5 through table 8 are unaffected by how I treat outliers. The results presented in table 5 through table 8 are very conservative results compared to untabluated results where I include or exclude outliers. 
tions from the pre- and post-Reg G observations respectively to mitigate concerns that the post-Reg G EQRANK is partially based on the pre-Reg $\mathrm{G}$ time-series. In untabulated results, I found that my inferences on EQRANK across two time periods did not change.

\section{Alternative news dates.}

Following Regulation G, firms must file a Form 8-K within four days indicating the GAAP and non-GAAP amounts and the reason why management believes the non-GAAP measure is useful to investors. One may infer that there could be significant market reactions surrounding these Form 8-Ks as they are furnished. To address this issue, I collected all 8-K announcements released on or within four days of the post-Reg G earnings announcement dates used in Table ${ }^{6 .}{ }^{22)}$ Using alternative $8-\mathrm{K}$ release dates, I estimated equation (3). I also test whether inferences are altered when I use longer windows such as five-day or eight-day window. I did not find any significant change in the post-Reg G estimation (untabulated).

\section{CONCLUSION}

In response to the highly publicized alleged misuse of pro-forma earnings disclosures, the U.S. Congress ordered the Securities and Exchange Commission (SEC) to issue new rules governing the presentation of non-GAAP financial metrics. The goal was to improve the quality and transparency of financial accounting information (Section 401(b) of the Sarbanes-Oxley Act of 2002). The SEC released Regulation G (SEC 2003a, hereinafter referred to as "Reg G") in January of 2003. Reg G requires firms that disclose non-GAAP earnings in preliminary earnings announcements to clearly reconcile non-GAAP earnings to GAAP earnings with equal emphasis on both figures. Recent studies by Heflin and Hsu (2005) and Marques (2006) and a survey by the National Investor Relations Institute (2003) have documented a significant decline in non-GAAP earnings

22) If there was one $8-\mathrm{K}$ within this window, I assumed that paticular 8 - $\mathrm{K}$ contained non-GAAP related reconciliation information. If there was more than one 8-K (73 cases) filed within this four-day window, I manually checked the right 8-K release date. The mean difference between earnings announcement date and 8 -K release date was 0.48 days $(\mathrm{p} 25=0$, median $=0, \mathrm{p} 75=1$ ), implying that firms furnish $8-\mathrm{K}$ immediately after earnings announcements in most cases. 
disclosures after the SEC intervention. This paper examines whether the decreased frequency of non-GAAP earnings disclosures post-Reg $G$ reflects intended or unintended consequences of Reg $G$ (and the Sarbanes-Oxley Act of 2002).

Given that Reg $G$ addresses the presentation format of a specific voluntary disclosure item in earnings announcements, I recognize two conflicting, but not mutually exclusive, strategic disclosure motives reported in prior literature in this study. In addition, I focus on adjusted EPS numbers by managers instead of actual EPS provided by forecast data providers because I believe the first order impact from Reg G is on managers' behaviors rather than sell-side analysts' behaviors.

Based on the hand-collected dataset from actual earnings announcements, I find that non-GAAP earnings disclosures are more pronounced by firms that have communication motives, proxied by historically low returns- GAAP earnings relation, in the post-Reg G period than in the pre-Reg G period. In contrast, non-GAAP earnings disclosures are less pronounced by firms that have opportunistic motives, proxied by GAAP loss and negative GAAP EPS changes, in the post-Reg G period than in the pre-Reg G period.

I also provide evidence that while incremental information content of non-GAAP earnings from sample firms increased after Reg $\mathrm{G}$, negative associations between income increasing non-GAAP adjustments and future returns and future operating income have decreased after Reg G. Further analyses indicate that these effects are mainly due to firms that stopped disclosing non-GAAP earnings post Reg G. Evidence presented in this paper indicate that there were firms that disclosed less value-relevant, less transitory, and misleading non-GAAP adjustments in the pre-Reg G period and Reg G has discouraged these firms from disclosing non-GAAP earnings post Reg G.

Overall, the findings of this paper appear consistent with Congress' and the SEC's intervention in pro-forma reporting practices resulting in improvements in the quality of information provided in non-GAAP earnings disclosures by discouraging opportunistic managers' presentation of non-GAAP earnings disclosures. 


\section{APPENDIX (VARIABLE DEFINITIONS)}

\begin{tabular}{|c|c|}
\hline BIGBATH & $\begin{array}{l}\text { An indicator coded as } 1 \text { if the sign of special items is negative } \\
\text { and LOSS is } 1,0 \text { otherwise, following Heflin and Hsu (2005). }\end{array}$ \\
\hline BTM & Book-to-market ratio. \\
\hline CONSENSUS & $\begin{array}{l}\text { An indicator variable, coded as } 1 \text { if the GAAP EPS excluding } \\
\text { extraordinary items and discontinued operations (dilution } \\
\text { factor considered) is less than the mean EPS estimate from } \\
\text { the } I / B / E / S \text { summary file. For REIT (real estate investment } \\
\text { trust) firms, I use FFO (funds from operations) forecast for } \\
\text { the comparison, if available. }\end{array}$ \\
\hline$E Q$ & 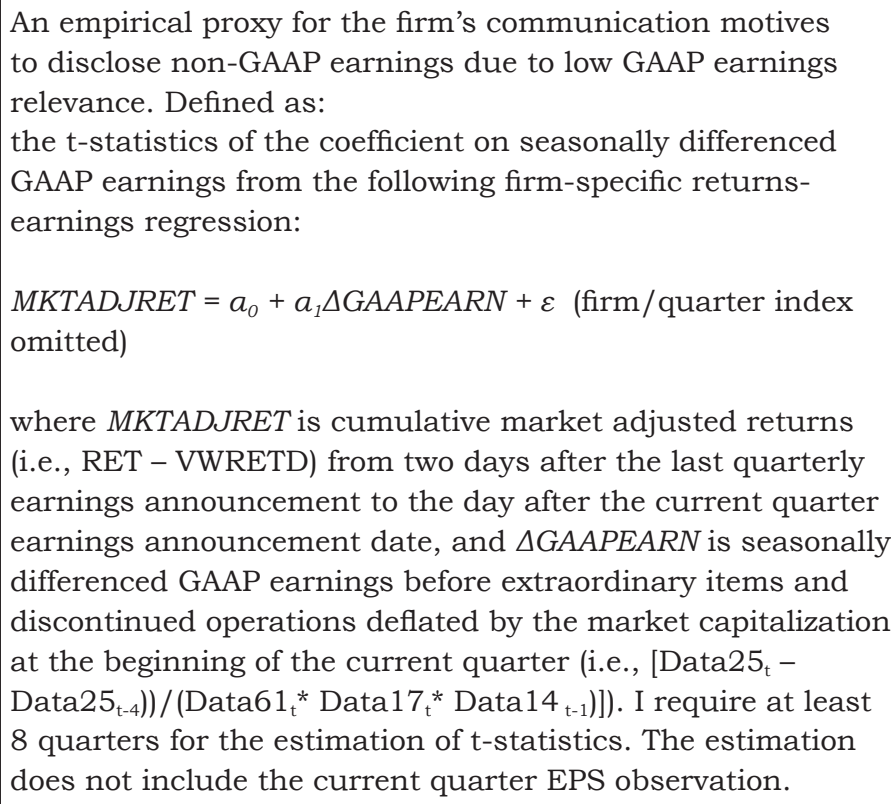 \\
\hline EQRANK & $\begin{array}{l}\text { EQRANK is a rank transformed variable from EQ. I rank } \\
\text { EQ by the calendar quarters in which preliminary earnings } \\
\text { announcements were issued, assigning from } 0 \text { (lowest EQ) } \\
\text { to } 99 \text { (highest EQ). EQRANK is designed to facilitate the } \\
\text { interpretation of the coefficient and the marginal effect of the } \\
\text { EQ variable in the probit regression model across different } \\
\text { regulatory regimes. }\end{array}$ \\
\hline $4 T H Q T R$ & $\begin{array}{l}\text { An indicator coded as } 1 \text { if the fiscal quarter of a firm is } 4,0 \\
\text { otherwise }\end{array}$ \\
\hline
\end{tabular}




\begin{tabular}{|c|c|}
\hline HHI & $\begin{array}{l}\text { Hirschmann-Herfindahl's index of market concentration (an } \\
\text { indicator of competition among firms), defined for firm } i \text { as } \\
\sum_{i=1}^{n}\left(\frac{\text { sales }_{i}}{\sum_{i=1}^{n} \text { sales }_{i}}\right)^{2} \text { where } n \text { denotes the number of firms in } \\
\text { each industry broken down by } 2 \text { digit SIC code and } i \text { denotes } \\
\text { a firm in the industry. Higher HHI values in a given industry } \\
\text { can translate into less competition in the market. }\end{array}$ \\
\hline HIGHTECH & $\begin{array}{l}\text { An indicator coded as } 1 \text { if the firm's SIC code falls in } 283 \text {, } \\
357,481,360-367 \text {, or } 873 \text { following Marques (2006). }\end{array}$ \\
\hline INTANGIBLE & $\begin{array}{l}\text { The total intangible assets divided by the total assets } \\
\text { (from annual data). I assign } 0 \text { if this item is missing in } \\
\text { COMPUSTAT. The same non-missing value was assigned for } \\
\text { other quarters in the same year. }\end{array}$ \\
\hline LEVERAGE & Total liabilities divided by total assets. \\
\hline LITIGATIONIND & $\begin{array}{l}\text { An indicator coded } 1 \text { for the high litigation industries (i.e., } \\
\text { SIC codes } 2833 \sim 2836,3570 \sim 3577,7370 \sim 7374,3600 \sim 3674) \\
\text { following Francis, Philbrick, and Schipper (1994). }\end{array}$ \\
\hline LNMKT & Log of market value at the end of quarter. \\
\hline LOSS & $\begin{array}{l}\text { An indicator coded as } 1 \text { if the GAAP EPS excluding } \\
\text { extraordinary items and discontinued operations for the } \\
\text { quarter is negative, } 0 \text { otherwise. }\end{array}$ \\
\hline NES & $\begin{array}{l}\text { An indicator coded as } 1 \text { if the seasonally differenced GAAP } \\
\text { EPS is declining (i.e. negative GAAP earnings changes), } 0 \\
\text { otherwise. }\end{array}$ \\
\hline$N G$ & $\begin{array}{l}\text { An indicator coded as } 1 \text { if the firm disclosed non-GAAP } \\
\text { earnings disclosure, } 0 \text { otherwise. }\end{array}$ \\
\hline PRIORNG & $\begin{array}{l}\text { An indicator coded as } 1 \text { if the firm issued non-GAAP } \\
\text { earnings in the prior quarter, } 0 \text { otherwise. }\end{array}$ \\
\hline$R O A$ & $\begin{array}{l}\text { Return on assets defined as earnings before earnings } \\
\text { excluding extraordinary items and discontinued operations } \\
\text { divided by the average total assets }\end{array}$ \\
\hline SI & $\begin{array}{l}\text { The amount of special items deflated by the total assets. } 0 \\
\text { was assigned for missing values. }\end{array}$ \\
\hline STDROA & The standard deviation of ROA from the prior eight quarters \\
\hline
\end{tabular}




\section{REFRENCES}

Abarbanell, J., and R. Lehavy (2007), "Letting the "Tail Wag the Dog": The Debate over GAAP versus Street Earnings Revisited," Contemporary Accounting Research, 24, 675-723.

Amir, E., and J. Livnat (2005), "The Economic Consequences of not Issuing Preliminary Earnings Announcement," Working Paper, London Business School.

Ai, C., and E. Norton (2003), "Interaction terms in logit and probit models," Economics Letters, 80, 123-129.

Babington, D (2003), "New earnings rules bring new investor concerns," Reuters News. (April 25, 2003).

Baik, B., B. Billings, and R. Morton (2008), "Reliability and Transparency of Non-GAAP Disclosures by Real Estate Investment Trusts (REITs)," The Accounting Review, 83, 271-301.

Barth, M., W. Beaver, and W. Landsman (1998), "Relative valuation roles of equity book value and net income as a function of financial health," Journal of Accounting and Economics, 25, 1-34.

Belsley, D. A., Kuh, E. and Welsch, R. E (1980), "Regression Diagnostics, Identifying Influential Data and Sources of Collinearity," New York, NY, John Wiley and Sons, Inc.

Bhattacharya, N., E. Black., T. Christensen, and C. Larson (2003), "Assessing the relative informativeness and permanence of pro-forma earnings and GAAP operating earnings," Journal of Accounting and Economics, 36, 285-319.

, and R. Mergenthaler (2007), "Who trades on Pro Forma Earnings Information?," The Accounting Review, 82, 581-619.

Blitzer, D., and R. Friedman (2002), "Measures of core earnings. Standard \& Poor's" (May 14, 2002).

Bowen, R., A. Davis, and D. Matsumoto (2005), "Emphasis on pro-forma versus GAAP earnings in quarterly press releases, determinants, sec intervention, and market reactions," The Accounting Review, 80, 10111038.

Bradshaw, M (2003), "A discussion of 'assessing the relative informativeness and permanence of pro-forma earnings and GAAP operating earnings," Journal of Accounting and Economics, 36, 321-335.

, and R. Sloan (2002), "GAAP versus the Street, An empirical assessment of two alternative definitions of earnings," Journal of Accounting Research, 40, 41-65.

Brown, L., and K. Sivakumar (2003), "Comparing the value relevance of two operating income measures," Review of Accounting Studies, 8, 561-572.

Brown, N., T. Christensen, B. Elliott, and R. Mergenthaler (2012), "Investor 
Sentiment and Pro Forma Earnings Disclosures," Journal of Accounting Research, 50, 1-50.

Christensen, T. (2007), "Discussion of "Letting the 'Tail Wag the Dog': The Debate over GAAP versus Street Earnings Revisited," Contemporary Accounting Research, 24, 741-762.

Cohen, D., A. Dey., and T. Lys (2008), "Real and Accrual-based Earnings Management in the Pre- and Post-Sarbanes Oxley Periods," The Accounting Review, 82, 757-787.

Collins, D., E. Maydew., and I. Weiss (1997), "Changes in the Value-Relevance of Earnings and Book Values over the Past Forty Years," Journal of Accounting and Economics, 24, 39-67.

Countryman, A (2003), "Some corporations continue to record routine expenses as special charges," Chicago Tribune (October 26, 2003).

Daniel, K., Grinblatt, M., Titman, S., Wermers, R. (1997), "Measuring Mutual Fund Performance with Characteristic-based Benchmarks," Journal of Finance, 52, 1035-1058.

Dechow, P. and C. Schrand (2004), "Earnings Quality," Research Foundation of CFA Institute. Charlottesville, VA.

Dietrich, J., S. Kachelmeier, D. Kleinmuntz, and T. Linsmeier (2001), "Market efficiency, bounded rationality, and supplemental business reporting disclosures," Journal of Accounting Research, 39, 243-268.

Doyle, J., J. Lundholm, and M. Soliman (2003), "The predictive value of expenses excluded from 'pro-forma' earnings," Review of Accounting Studies, 8, 145-174.

Doyle, J., W. Ge., and S. McVay (2007), "Determinants of weaknesses in internal control over financial reporting," Journal of Accounting and Economics,.44, 193-223.

, J. Jennings, and M. Soliman (2011), "Do Managers Define NonGAAP Earnings to Meet or Beat Analyst Forecasts?” Working Paper, Stanford University.

Elliott, W (2006), "Are Investors Influenced by Pro Forma Emphasis and Reconciliations in Earnings Announcements?," The Accounting Review, 81, 113-133.

Frankel, R. and S. Roychowdhury (2004), "Testing explanations for the difference between I/B/E/S and GAAP Earnings," Working Paper, MIT.

, S. McVay, M. Soliman (2011), "Non-GAAP earnings and board independence" Review of Accounting Studies, 16, 719-744.

Francis, J., D. Philbrick., and K. Schipper (1994), "Shareholder Litigation and Corporate Disclosures," Journal of Accounting Research, 32, 137164.

, and K. Schipper (1999), "Have Financial Statements Lost Their Relevance," Journal of Accounting Research, 37, 319-352.

Frederickson, J. and J. Miller (2004), "Pro-forma earnings disclosures, Do 
analysts and nonprofessional investors react differently?," The Accounting Review, 79, 667-686.

Gibbins, M., A. Richardson, and J. Waterhouse (1990), "The management of corporate financial disclosure, Opportunism, ritualism, policies, and processes," Journal of Accounting Research, 28, 121-143.

Goff, J (2001), "Finance executives pro pro-forma, says CFO.com poll," CFO Magazine, (November 16, 2001).

Graham J., C. Harvey, and S. Rajgopal (2005), "The economic implications of corporate financial reporting," Journal of Accounting and Economics, 40, 3-73.

Gu, Z., and T. Chen (2004), "Analysts' Treatment of Nonrecurring Items in Street Earnings," Journal of Accounting and Economics, 38, 129-170.

Heflin, F., and C. Hsu (2011), "The impact of the SEC's regulation of nonGAAP disclosures," Journal of Accounting and Economics, 46, 349-365.

Henry, D (2003), “Ouch! real numbers," Business Week, (March 24, 2003)

Hirshleifer, D., and S. Teoh (2003), "Limited attention, financial reporting and disclosure," Journal of Accounting and Economics, 36, 337-386.

Hobson, J., and S. Kachelmeier (2005), "Strategic Disclosure of Risky Prospects: A Laboratory Experiment," The Accounting Review, 80, 825-846.

Kinney, M., and R. Trezevant (1997), "The use of special items to manage earnings and perceptions," The Journal of Financial Statement Analysis, Fall, 45-53.

Kolev, K, C. Marquardt, and S. McVay (2008), "SEC scrutiny and the evolution of non-GAAP reporting," The Accounting Review 83, 157-184.

Kothari, SP., J. Sabino, and T. Zach (2005), "Implications of survival and data trimming on tests of market efficiency," Journal of Accounting \& Economics, 39, 129-161.

Lev, B. and P. Zarowin (1999), "The Boundaries of Financial Reporting and How to Extend Them," Journal of Accounting Research, 353-385.

Lougee, B., and C. Marquardt (2004), "Earnings quality and strategic disclosure, An empirical examination of pro-forma earnings," The Accounting Review 79, 769-795.

Maines, L., and L. McDaniel (2000), "Effects of comprehensive-income characteristics on nonprofessional investors' judgments, the role of financial-statement presentation format," The Accounting Review 75, 179207.

Marques, A (2006), "SEC intervention and the frequency and usefulness of non-GAAP financial measures," Review of Accounting Studies 11, 549574.

Miller, G (2002), "Earnings performance and discretionary disclosure," Journal of Accounting and Research 40, 173-204.

McVay, S (2006), "The use of special items to inflate core earnings," The Accounting Review, 81, 501-531. 
National Investor Relations Institute (NIRI) (2001), "Earnings press release guidance," Vienna, VA, NIRI. (April 26, 2001). (2002), "NIRI Guidelines to Improve Earnings Releases," Vienna, VA, NIRI. (October 8, 2002).

(2003), "Information Dissemination under Regulation G," Vienna, VA, NIRI. (April 15, 2003).

Norton, E., H. Wang, and C. Ai (2004), Computing interaction effects and standard errors in logit and probit models," The STATA Journal, 4, 103116.

Schrand, C., and B. Walther (2000), "Strategic benchmarks in earnings announcements, The selective disclosure of prior-period earnings components," The Accounting Review, 75, 151-177.

Securities and Exchange Commission (SEC) (2001), "Cautionary advice regarding the use of "pro-forma" financial information in earnings releases," Release No. 33-8039. (December 4, 2001).

(2003a), "Conditions for Using non-GAAP Financial Measures," Release No. 33-8176. (March 28, 2003).

(2003b), "Testimony Concerning Implementation of the SarbanesOxley Act of 2002," available at www.sec.gov (September 9, 2003).

Stuart, A. N (2004), "A matter of emphasis, Regulation G was supposed to end the abuses of pro-forma reporting. Has it succeeded?," CFO Magazine, (July 7,2004$)$.

Taub, S (2001), "Finance executives pro pro-forma, says CFO.com poll," CFO Magazine (November 8, 2001).

S (2003), "A hard line on financial reporting didn't deter a small group from their pro-forma ways," CFO Magazine (August 13, 2003).

Thompson, L (2003), "IR, Poised for Change and New Opportunities," available at http, //www.niri.org (November 4, 2003).

Thurm, S., and J. Weil (2001), "Tech Companies Charge Now, May Profit Later," The Wall Street Journal, (April 27, 2001).

Vincent, L (1999), "The information content of funds from operations (FFO) for real estate investment trusts (REITs)," Journal of Accounting and Economics, 26, 69-104.

Wallace, W (2002), "Pro-forma before and after the sec's warning, a quantification of reporting variances from GAAP," Florham Park, NJ, Financial Executives Research Foundation.

Weil, J (2001), "Ignore the items behind the curtain, EPS means different things to different earnings," The Wall Street Journal (16 October 2001, C2).

White, H (1980), "A Heteroskedasticity-Consistent Covariance Matrix and a Direct Test for Heteroskedasticity," Econometrica, 48, 817-838.

Wooldridge, J (2002), "Econometric Analysis of Cross Section and Panel Data," Cambridge, MA, The MIT Press. 
Zhang, H., and L. Zheng (2011), "The valuation impact of reconciling pro forma earnings to GAAP earnings," Journal of Accounting and Economics, 51, 186-202.

Zhang, I (2007), "Economic consequences of the Sarbanes-Oxley Act of 2002," Journal of Accounting and Economics, 44, 74-115.

Received July 10, 2012

Accepted September 12, 2012 
